\begin{tabular}{|c|c|c|}
\hline \multirow{2}{*}{$\begin{array}{l}\text { Cellular Physiology } \\
\text { and Biochemistry }\end{array}$} & \multicolumn{2}{|c|}{ Cell Physiol Biochem 2019;52:280-301 } \\
\hline & $\begin{array}{l}\text { DOI: } 10.33594 / 0000000021 \\
\text { Published online: } 28 \text { February } 2019 \\
\text { Accepted: } 10 \text { January } 2019\end{array}$ & 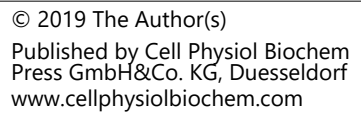 \\
\hline
\end{tabular}

Review

\title{
Acid Sphingomyelinase-Ceramide System in Bacterial Infections
}

\author{
Cao Lia Anni Wang ${ }^{b}$ Yuqing Wuc Erich Gulbins ${ }^{c, d}$ Heike Grassméc \\ Zhigang Zhao ${ }^{a}$
}

aDepartment of Pharmacy, Beijing Tiantan Hospital, Capital Medical University, Beijing, PR China, bDepartment of Clinical Pharmacology, School of Pharmaceutical Sciences, Capital Medical University, Beijing, PR China, 'Department of Molecular Biology, University of Duisburg-Essen, Essen, Germany, dDepartment of Surgery, University of Cincinnati, Cincinnati, $\mathrm{OH}$, USA

\section{Key Words}

Ceramide • Sphingomyelinase - Bacterial infections • Cystic fibrosis • Sphingosine • Sphingolipids

\begin{abstract}
Acid sphingomyelinase hydrolyzes sphingomyelin to ceramide and phosphorylcholine. Ceramide molecules spontaneously interact with each other and generate ceramide-enriched membrane domains. These ceramide-enriched domains further fuse, forming large ceramideenriched platforms that participate in the organization of receptors and in the amplification of signaling molecules. Recent studies have suggested several bacteria and bacterial toxins that stimulate the activation and the translocation of acid sphingomyelinase, which leads to the release of ceramide. The acid sphingomyelinase/ceramide system also regulates the internalization of bacteria into the host cell, the subsequent cytokine release, inflammatory response, and initiation of host cell apoptosis. In addition, ceramide has been implicated in the fusion of phagosomes and lysosomes upon bacterial infection. Thus, this system modulates the reorganization of cell membrane receptors and intracellular signaling molecules during bacteria-host interactions. The acid sphingomyelinase and ceramide system may thus serve as a novel therapeutic target for treating infections.

(C) 2019 The Author(s). Published by Cell Physiol Biochem Press GmbH\&Co. KG

\section{Introduction}

Although sphingolipids have long been considered as structural components of cell membranes, recent studies have revealed their crucial functions in the regulation of physiological and pathological processes. In host-bacteria interactions, sphingolipids play an important role in the regulation of the balance between the host and the microbe $[1,2]$. Sphingomyelin is the most abundant sphingolipid, comprising $2 \%-15 \%$ or even higher of the total phospholipid in specific tissues [3]. Sphingomyelin can be hydrolyzed




\section{Cellular Physiology Cell Physiol Biochem 2019;52:280-301 \\ \begin{tabular}{ll|l} 
and Biochemistry Published online: 28 February 2019 & C 2019 The Author(s). Published by \\
Cell Physiol Biochem Press GmbH\&Co. KG
\end{tabular} \\ Li et al.: Sphingolipids and Infections}

by sphingomyelinases, which breakdown the phosphodiester bond to generate ceramide. Sphingomyelinases are characterized and identified as acid, neutral and alkaline sphingomyelinases based on the optimal $\mathrm{pH}$ of their activity. Acid sphingomyelinase (abbreviated here uniformly as ASM for the human and murine protein), the most studied of these 3 enzymes, is critically involved in many aspects of cell signaling [4]. ASM is characterized for its central role in the re-organization of molecules within the cell upon diverse stimuli and upon the induction of apoptosis, as well as cellular differentiation, proliferation, tumor presentation, cardiovascular disease, and bacterial infections [for review see for instance ref. 4].

Antibiotics have long been preferred and effective treatments for bacterial infections. However, antibiotic resistance has become a severe threat to global public health. The lack of efficacious strategies for treating bacterial infections leads to a worsened clinical outcome, including death, and marked financial costs. Thus, it is important and urgent to identify novel therapeutic targets to fight against bacterial infections. In this review, we will focus on ASM and provide an overview of the regulation and activation of ASM and ASM-generated lipid domains in the process of bacterial infections. We will also discuss the regulation of the host immune system by ASM.

\section{Acid sphingomyelinase}

Acid sphingomyelinase plays an important role in sphingolipid metabolism and is responsible for hydrolyzing sphingomyelin to ceramide and phosphorylcholine. The ASM gene is $5-6 \mathrm{~kb}$ long, localizes to chromosome 11p15.1-11p15.4 and contains six exons and five introns [5, 6]. Human ASM cDNA encodes a polypeptide of 629 amino acids [7, 8], which shares approximately $82 \%$ amino acid identity with murine acid sphingomyelinase [9]. ASM consists of three main domains: the N-terminal saposin domain, the proline-rich connector, and the catalytic domain $[10,11]$. ASM deficiency results in the accumulation of sphingomyelin and causes lysosomal storage diseases, i.e., the fatal neuropathic and visceral disease Niemann-Pick type A and the visceral anomalies disease Niemann-Pick type B [6, 12-14].

It was reported that ASM has an optimal $\mathrm{pH}$ of 4.5-5.0 for activity [15], however, the ASM also catalyzes the hydrolysis of LDL-sphingomyelin on the plasma membrane at a higher, or almost neutral, $\mathrm{pH}[16,17]$. The single ASM gene generates two distinct enzymes: a lysosomal form of ASM (L-ASM) and a secretory form of ASM (S-ASM). The generation of two forms of ASM results from alternative modification and trafficking. The mutation of $\mathrm{N}$-glycosylation sites affects the catalytic activities and intracellular processes of L-ASM and S-ASM [18]. Previous studies have shown that the mannose-6-phosphorylation (M6P) receptor system mediates lysosomal trafficking of ASM $[19,20]$. Additional studies have been reported indicating that the trans-Golgi network (TGN) transmembrane protein sortilin plays a critical role in L-ASM trafficking along a Golgi-dependent route [19, 21, 22]. The pre-pro-form of ASM with a $75 \mathrm{kDa}$ ( $65 \mathrm{kDa}$ protein core) molecular weight enters the Golgi, thereby generating the pro-form of ASM with a 72-75 kDa (63-64 kDa protein core) [23]. L-ASM translocates to the lysosome as a $57 \mathrm{kDa}$ (43 kDa protein core) [24] or a $65 \mathrm{kDa}$ (55 $\mathrm{kDa}$ protein core) enzyme [24-26]. The activation of S-ASM is dependent on exogenous $\mathrm{Zn}^{2+}$, whereas L-ASM binds to $\mathrm{Zn}^{2+}$ ions on its way to lysosomal compartments, resulting in the independence of exogenous $\mathrm{Zn}^{2+}$ [17]. Although several groups have studied the ASM, only a few studies have discussed the precise molecular mechanism in the regulation of the lysosomal and secretory forms of ASM.

Various stimulations can regulate the activation of ASM, i.e., reactive oxygen species (ROS), proteases, death receptors, irradiation, phosphorylation, and pathogen infections. For example, hydrogen peroxide induces an activation of ASM in different cells [27-29]. In accordance, inhibition of ROS by several ROS scavengers such as TIRON, N-acetylcysteine (NAC), superoxide dismutase (SOD), catalase or the nicotinamide adenine dinucleotide 


\section{Cellular Physiology Cell Physiol Biochem 2019;52:280-301 \\ \begin{tabular}{ll|l} 
and Biochemistry Published online: 28 February 2019 & C 2019 The Author(s). Published by \\
Cell Physiol Biochem Press GmbH\&Co. KG
\end{tabular} \\ Li et al.: Sphingolipids and Infections}

phosphate (NADPH)-oxidase inhibitor diphenyleneiodonium chloride (DPI) blocked the activation of ASM induced by different stimulations [29-33]. Genetic silencing of NADPH oxidase subunit gp91 $1^{\text {phox }}$ also inhibited ASM activation [34]. In vitro studies indicated that the direct oxidation of ASM at the C-terminal cysteine residue 629 results in activation of enzymes [35]. These findings indicate that ROS is required for the activation of ASM, although it remains unclear whether ROS regulates the enzyme activity directly or indirectly $[4,36]$.

\section{ASM-generated ceramide formation}

Ceramide is commonly considered as the backbone of sphingolipids, which are one of the main components of the plasma membrane. Ceramide can be generated from several pathways, including the hydrolysis of sphingomyelin by sphingomyelinase, de novo synthesis, the salvage pathway and the hydrolysis of complex glycosylated lipids [37]. There are more than 28 distinct enzymes regulating ceramide metabolism as a substrate or product [38-44].

Ceramide is composed of a D-erythro-sphingosine backbone and fatty acid-containing acyl chains of different lengths connected via an amide ester bond $[45,46]$. It contains a hydroxyl functional group, an amide linkage and an $\mathrm{OH}$ group on a sphingosine backbone, which forms hydrogen bonds. The hydrophilic hydrogen bonds and hydrophobic moieties result in the spontaneous separation of ceramides from other phospholipids and the formation of distinct micro lipid domains $[47,48]$. Upon activation of ASM, ceramide molecules generated from sphingomyelin spontaneously interact with each other, forming small ceramide-enriched membrane domains. These small ceramide-enriched domains function in signaling transduction and can further fuse to large ceramide-enriched domains, termed platforms [49-51].

The generation of ceramide by ASM alters the physiological properties of the biological membranes. The ceramide-enriched platforms re-organize receptors and signaling molecules upon various stimulations. The formation of ceramide-enriched domains can be visualized by fluorescence staining $[47,48]$. Ceramide-enriched platforms occur in cells upon diverse receptor or non-receptor stimuli, including CD95 [52-55], Fc $\gamma$ RII [56], DR5 [33], CD40 [57], platelet-activating factor receptor (PAF) [58], viral infection [59-61], N. gonorrhoeae [62], S. aureus [31], P. aeruginosa [29, 63]; pyocyanin [27], cisplatin [64], $\mathrm{Cu}^{2+}$ [32], irradiation [65], and UV-light [66, 67]. CD95 and DR5 belong to the family of death receptors and induce programmed cell death, i.e. apoptosis. PAF receptor present in platelets, but also in other cells of the cardiovascular system, such as endothelial cell, that plays an important role in coagulation, endothelial dysfunction and shock. Fc $\gamma$ RII. CD40 are receptors that are present in immune cells, mainly B-lymphocytes, and serve as important co-receptors. Pyocyanin is produced by $P$. aeruginosa and functions as a toxin that regulates redox sensitive targets in mammalian cells. Cisplatin is a commonly used chemotherapeutic drug. The interaction of ceramide-enriched platforms with CD95 is one of the best-studied stimulations. CD95 induces the activation and translocation of ASM onto the outer leaflet of the plasma membrane, thus generating ceramide [52, 54]. Ceramide generation and aggregation forms a ceramide-enriched membrane platform, which results in the clustering of CD95 within a confined area of the membrane and amplification of CD95 signaling [52-54]. The disruption of these ceramide-enriched membrane domains abolishes CD95 assembly with downstream signaling molecules [68].

\section{ASM in bacterial infections}

Various studies have shown that the ASM/ceramide system plays a critical role in a wide range of cellular processes, such as cell death, proliferation, growth and differentiation [32, 69-71]. Alterations in the ASM/ceramide system are involved in several physiological and pathological processes, such as genetic diseases [72, 73], tumor development [74, 
75], neurogenesis, neuronal integrity and behavior [76-79], atherosclerosis [80, 81], and infections with pathogens [31, 59-62]. Particularly, the interaction of bacterial infections and the ASM/ceramide system has emerged as a novel research direction. The studies related to ASM/ceramide and bacteria as well as bacteria-generated toxins are listed in Table 1.

\section{Pseudomonas aeruginosa (P. aeruginosa)}

P. aeruginosa is the most studied bacterium among all pathogens interacting with ASM. $P$. aeruginosa is a gram-negative bacterium commonly affecting immune-compromised patients and patients with cystic fibrosis, chronic wounds, sepsis, or chronic emphysema [82, 83]. Epidemiology studies have reported the high prevalence of $P$. aeruginosa with morbidity and mortality in chronic lung infections. Patients with cystic fibrosis have a particularly risk for chronic $P$. aeruginosa infections.

The infection of mammalian cells with different strains of $P$. aeruginosa induces the rapid activation of ASM, particularly, the translocation of ASM from intracellular compartments to the extracellular leaflet of the plasma membrane, where the ASM colocalizes with $P$. aeruginosa at the infection site [63]. Other studies have confirmed the activation of ASM and the generation of ceramide triggered by $P$. aeruginosa in various cells as well as mice [29]. P. aeruginosa activation results in generation of ceramide-enriched microdomains that spontaneously form ceramide-enriched platforms and that initiate lipid raft reorganization. These ceramide-rich rafts are essential for the internalization of P. aeruginosa into mammalian cells, which is prevented by the disruption of these rafts via pharmacological inhibitors of the ASM or by ASM-deficiency. This effect is consistent with the finding that clustering of cystic fibrosis conductance regulator (CFTR) in ceramide-enriched domains correlates with internalization of $P$. aeruginosa into respiratory epithelial cells $[63,84]$. Currently, the mechanisms how ceramide-enriched platforms regulate these signaling events are unknown.

ASM and the ceramide system in P. aeruginosa infection are also critically involved in cell apoptosis. ASM deficiency results in the failure of the formation of ceramide-enriched membrane platforms, which correlates with a lack of apoptosis in vitro and in vivo [63]. The exogenous addition of recombinant ceramide is sufficient to restore apoptosis in ASM-deficient epithelial cells. Ceramide is involved in either extrinsic (by stimulation of receptors for proteins from the TNF- $\alpha$ and CD95/Fas families) or intrinsic (mitochondria and ER metabolic stress mediated apoptosis) apoptotic pathways, which have been reviewed in detail $[85$, 86]. CD95 receptor molecules are concentrated in ceramide-enriched membrane platforms and likely induce cell apoptosis upon $P$. aeruginosa infection [63]. Another potential mechanism underlying ASMmediated $P$. aeruginosainduced cell death may be the amplification of redox signaling [29]. In freshly isolated macrophages, ASM is required for the activation of nicotinamide adenine dinucleotide phosphate (NADPH) oxidase and for the release of reactive oxygen

Table 1. ASM/ceramide system in bacterial infection

\begin{tabular}{lcc}
\hline Bacteria/toxin & Mechanism & References \\
\hline Pseudomonas aeruginosa & IL-1 release, septic death & {$[63]$} \\
& NADPH oxidase activation, ROS production & {$[29]$} \\
& gp91phox clustering, ROS production & {$[98]$} \\
& IL-8 release & {$[89]$} \\
& Pulmonary inflammation, epithelial cell death & {$[70]$} \\
& CD95 clustering, cell death & {$[173]$} \\
Staphylococcus aureus & Integrin accumulation, sphingosine depletion & {$[9]$} \\
& Cytochrome C release, endothelial cell apoptosis & {$[107]$} \\
& Superoxide formation, tight junction degradation & {$[31]$} \\
mycobacteria & CD44 interaction, phagolysosome maturation & {$[109]$} \\
& Granuloma formation & {$[132]$} \\
Listeria monocytogenes & Macrophage necrosis & {$[133]$} \\
& Phagosome maturation & {$[21]$} \\
Neisseria gonorrhoeae & Fusion of late phagosomes with lysosomes & {$[129]$} \\
Neisseria meningitidis & CEtokine release, reactive nitrogen release & {$[140]$} \\
Escherichia coli & Activation of PC-PLC & {$[144]$} \\
& Internalization of bacteria & {$[62]$} \\
Salmonella enterica & Dendritic cells apoptosis & {$[145]$} \\
Propionibacterium acnes & Cytokine release & {$[147]$} \\
LPS & ROS generation & {$[174]$} \\
& Hijacking host ASM & {$[154]$} \\
& Dendritic cell apoptosis & {$[158]$} \\
Pyocyanin & TNF- $\alpha$ and MIP-2 release & {$[147]$} \\
$\alpha$-toxin & Pulmonary inflammation & {$[162]$} \\
& Endothelial cell apoptosis & {$[154]$} \\
& Neutrophil cell death, ROS release & {$[165]$} \\
& $\alpha$-toxin binding, host cell necrosis & {$[27]$} \\
& Tight junction degradation & {$[11]$} \\
& Cathepsin release, inflammation & {$[121]$} \\
\hline
\end{tabular}


species (ROS), thereby activating c-Jun N-terminal kinase (JNK) triggered apoptosis. Two subunits of NADPH oxidase $\mathrm{p} 47^{\text {phox }}$ and gp $91^{\text {phox }}$ are required for ASM-regulated apoptosis in mammalian cells $[29,87]$.

In addition, ceramide is accumulated in the lungs of CFTR-deficient mice prior to any infection and is normalized by the heterozygosity of ASM. Increased ceramide concentrations mediate clustering of CD95 in the plasma membrane and apoptosis of lung epithelial cells $[52,55,88]$.

Deficiency or dysfunction of ASM plays a role in the release of cytokines in response to $P$. aeruginosa challenge. P. aeruginosa infection leads to an uncontrolled release of IL- $1 \beta$ from infected cells or from the lungs of ASM-deficient cells [63], whereas the addition of exogenous ceramide is sufficient to rescue the phenotype of ASM-deficient epithelial cells. Blocking ASM with multiple approaches, i.e., silencing, pharmacological inhibitors, or specific antibodies, significantly increased IL-8 release upon P. aeruginosa infection in epithelial cells [89]. On the other hand, apoptosis mediated through the ASM/ceramide system may physically limit the control of cytokine release [63]. This system might also influence cytokine release through regulating the synthesis or through interfering with gene transcription or protein expression of cytokines.

The ASM/ceramide system is essential for host defenses against $P$. aeruginosa infection. Mice with genetic ASM deficiency fail to clear P. aeruginosa pulmonary infections, and $90 \%$ of these animals died in 7 days [63]. Death might be caused by an over-activation of the immune system, since intravenous injection of neutralizing antibody against IL- $1 \beta$ successfully rescued ASM-deficient mice from lethal pneumonia caused by P. aeruginosa. Consistently, the decrease or absence of endogenous IL-1 activity suppresses pulmonary inflammatory responses, thereby improving the host defense against $P$. aeruginosa infection in the lungs [90]. The regulation of ROS production by the ASM/ceramide system is another mechanism involving bacteria killing [29]. NADPH oxidase is required for host defenses against invading pathogens because ROS are toxic to most bacteria. The deficiency of ASM and the absence of ceramide-enriched platforms abolish ROS production via NADPH oxidase in freshly isolated alveolar macrophages upon $P$. aeruginosa infection. Previous studies have indicated that JNK functions between NADPH oxidase-derived ROS production and apoptotic cell death in P. aeruginosa infection in phagocytes, which is consistent with recent studies [91]. ROS production is importantly involved in the redox regulation of host responses against $P$. aeruginosa, but this pathogen can actively block the ROS burst via the PI3K pathway using the two type III secreted effector proteins, ExoS and ExoT [92]. Particularly, ExoS interferes with the signaling cascade that mediates NADPH oxidase assembly by ADP-ribosylating Ras. Most of the events described in the internalization and elimination of intracellular bacteria require expression of the type III secretion system in P. aeruginosa $[93,94]$. Notably, it is unknown whether ceramide-enriched membrane platforms play a role in the transfer of bacterial proteins and delivery of bacterial cells into mammalian host cells via the type III secretion system.

The cleavage of the fatty acid moiety from ceramide by ceramidase produces sphingosine, a bioactive lipid that plays a prominent role in the pulmonary defense against $P$. aeruginosa. In both humans and mice with cystic fibrosis, an increase in ceramide and in the formation of ceramide platforms leads to an ectopic trapping and clustering of $\beta 1$-integrins on the luminal pole of bronchial epithelial cells [95]. $\beta 1$-integrin impairs the acid ceramidase (aCDase) activity and expression, consequently resulting in the accumulation of ceramide and the decrease in surface sphingosine. Reducing ASM activity with ASM pharmacological inhibitors amitriptyline or fluoxetine normalizes ceramide and sphingosine levels and $\beta 1$ integrin expression and prevents P. aeruginosa infection in CF mice. Sphingosine is abundantly expressed on the luminal surface of human nasal epithelial cells in healthy individuals and in the trachea of mice, but is almost undetectable in CF patients and in Cftr-deficient mice. In contrast, ceramide levels are elevated in CF mice. Inhalation of sphingosine eliminates existing $P$. aeruginosa infections and clears $P$. aeruginosa or $S$. aureus infections in CF mice [96, 97], whereas the pharmacologic or genetic normalization of ceramide prevents $P$. aeruginosa 
Fig. 1. Disruption of ceramidesphingosine balance in cystic fibrosis. In healthy cells and in individuals, a low ceramide and high sphingosine level maintains a balance. In contrast, abnormally high ceramide and low sphingosine levels activate several signaling pathways, such as integrin accumulation, CD95 activation, and proinflammatory and anti-inflammatory cytokines, in the airways of cystic fibrosis patients or cells.

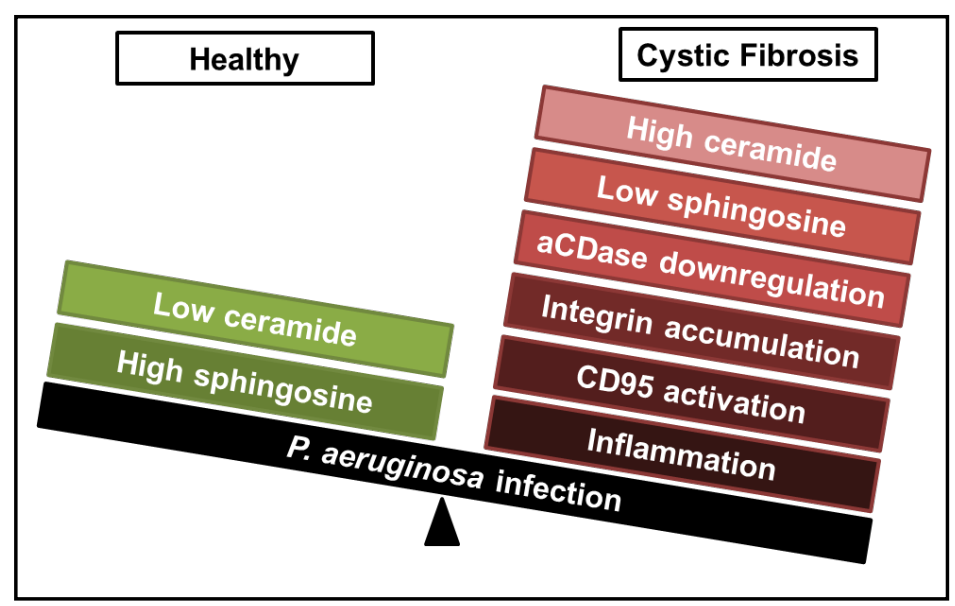

infection in CF mice $[30,70,98-100]$. In healthy cells, the ratio of ceramide to sphingosine is relatively stable and balanced. However, if this balance is disrupted as in CF, cells are highly susceptible to bacterial infections. Ceramide elevation induces acid ceramidase dysfunction and reduces sphingosine, integrin accumulation, and CD95 activation and eventually reduces uncontrolled inflammation (Fig. 1). This balance has been further demonstrated in S. aureus; the ASM/ceramide/acid ceramidase/sphingosine system in CF lungs and the correction of ceramide and sphingosine levels in bronchial epithelial cells prevent pulmonary infection [101].

Pyocyanin is a redox-active compound produced by $P$. aeruginosa, which easily accepts and donates electrons and crosses biological membranes, acting as a mobile electron carrier for $P$. aeruginosa [102]. The pyocyanin-induced rapid death of neutrophils depends on ASM, a novel mechanism for the activation of mitochondrial ASM in the generation of ROS in mitochondria [27]. Whether pyocyanin induces a change in mitochondrial membrane lipids has not yet been determined.

Currently, the function and regulation of mitochondrial ASM has not been extensively studied, although studies clearly showed mitochondrial expression of the enzyme, its association with pro-caspase 3-induced apoptosis [103] or the glutamate-induced regulation of necrosis [104]. In addition, ASM regulates the lipid composition of membranes.

\section{Staphylococcus aureus (S. aureus)}

S. aureus is a commensal opportunistic bacterium that colonizes approximately $30 \%$ of human populations. This bacterium frequently causes diseases from mild skin and soft tissue infections to life-threatening diseases, such as pneumonia, endocarditis, sepsis, and toxic shock syndrome [105]. The methicillin-resistant $S$. aureus (MRSA) has become a major pathogen and critical problem in both community and hospitals worldwide, particularly resulting from the lack of effective therapeutic approaches to control multiple antibioticresistant $S$. aureus infection [106].

In 2001, a study showed that $S$. aureus infection triggers ASM activation and ceramide production in human endothelial cells [107]. Genetic deficiency of ASM significantly inhibits the death of human fibroblasts triggered by $S$. aureus, which is mediated by stimulation of the JNK signaling pathway as well as alterations in mitochondrial function. The functional inhibition of JNK by Tam67 gene transfection prevents $S$. aureus-induced cell apoptosis. These results are consistent with the finding that ASM and ceramide-enriched platforms mediate macrophage apoptosis via the stimulation of JNK upon P. aeruginosa infection [29]. The endothelial cell death mediated by the ASM/ceramide system may cause the degradation of tight junction proteins and the breakdown of the endothelial cell barrier, enabling the 
bacterium to infect other tissues or organs. In cystic fibrosis airways, the accumulation of ceramide results in the membrane recruitment of inflammasome proteins and the activation of caspase 1 as well as the phosphorylation of JNK [108].

A recent study showed that genetic deficiency or pharmacological inhibition of ASM protects mice against pneumonia and lethal $S$. aureus sepsis [31]. ASM is activated by $S$. aureus in endothelial cells; subsequently, ceramide-enriched platforms are generated. ASM activation triggers the release of superoxide, whereas ASM activation is inhibited by antioxidants. The ASM/ceramide system and ROS act as a positive feedback loop mechanism upon $S$. aureus infection, which is similar to the findings of previous studies [29]. Another mechanism in $S$. aureus activated ASM involves CD44, a glycoprotein that interacts with Ezrin/Radixin/Moesin (ERM) and links the actin cytoskeleton to the plasma membrane and extracellular matrix [109]. Macrophages are activated via CD44 upon infection with $S$. aureus, thereby stimulating the activation of ASM and the release of ceramide. In addition, ASM/ceramide-triggered superoxide production induces the degradation of tight junction proteins Z01, ZO2, occludin and E-cadherin upon S. aureus infection in vitro or in vivo, an effect that was ameliorated by the inhibition of ASM via amitriptyline or antioxidants. Several studies have demonstrated that superoxide is responsible for the degradation of tight junctions via proteolytic matrix metalloproteinases (MMP) [110-112]. Moreover, ASM was shown to positively regulate the mRNA transcription and protein expression of MMP [113-115].

S. aureus is the primary cause of sepsis and lethal lung edema, even with the clinical administration of antibiotics. Mice treated with the ASM inhibitor amitriptyline or lacking ASM expression show reduced lung edema, because degradation of tight junctions was decreased and thereby myeloid cell trafficking was inhibited [31]. However, on the other hand the bactericidal capacity is also reduced since ASM dysfunction leads to the failure of clustering and activation of NADPH oxidase, resulting in the susceptibility and high mortality of mice to $S$. aureus infection. ASM inhibition was achieved using functional inhibitors, such as imipramine, desipramine and amitriptyline, which displace the ASM from the lysosomal membrane resulting in degradation of the enzyme and, thus, a functional inhibition $[4,79]$. Functional ASM inhibitors also improve endothelial stresses response during sepsis [116]. The activity and expression of plasma ASM increased depending on the severity of sepsis in patients. Freshly isolated serum from patients with sepsis instantaneously induces the breakdown of sphingomyelin and the elevation of ceramide in endothelial cells, an effect that is abrogated by desipramine. The inhibition of ASM by pre-incubation with desipramine or NB6 blocks the clustering of receptor complexes, such as the CD95L/Fas-receptor, as well as the formation of ceramide-enriched microdomains.

The precise mechanism of ASM activation upon S. aureusinfection is far from understood; extended studies have demonstrated that Staphylococcal alpha-toxin ( $\alpha$-toxin) is one of the factors mediating the activation of ASM and leading to detrimental effects of the pathogen on endothelial cells [117]. The $\alpha$-toxins, a class of $\beta$-barrel pore-forming cytotoxins, are major host injurious toxins secreted by $S$. aureus, and these molecules function by forming pores in cell membranes, damaging membrane permeability, and eventually triggering cell death [118-120]. ASM is rapidly activated by the wild-type $S$. aureus strain as well as by purified $\alpha$-toxins, whereas the $\alpha$-toxin-deficient JE2- $\Delta$ hla mutant strain has no effect on ASM activity. Pre-incubation with the ADAM10 inhibitor GI254023X or $\beta$-cyclodextrin, which blocks toxins by binding to toxin heptamers, markedly decreases ASM activation upon cellular stimulation with $\alpha$-toxin. S. aureus $\alpha$-toxin induces the degradation of tight junctions in endothelial cells, which is abrogated by the inhibition of ASM or ADAM10. Furthermore, while infection with $S$. aureus JE2 results in severe pneumonia in CF mice, the deletion of $\alpha$-toxin by $\beta$-cyclodextrin reduces the pathogenicity of $S$. aureus. Also, the inhibition of ceramide generation by the application of amitriptyline is beneficial to prevent infection [101]. These studies reveal a central role for $\alpha$-toxin and ASM in S. aureus infection. Another study from the same group demonstrates a novel signaling pathway, in which $\alpha$-toxin activates ASM and triggers the formation of ceramide in lysosomes of macrophages [121]. Activation of the ASM/ceramide 
system in macrophages induces the release of cathepsin B from lysosomes into the cytoplasm, associated with Nlrc4 and Asc, as well as eventual activation of the inflammasome and release of IL$1 \beta$. These studies connect the lysosomal ASM/ceramide system with the regulation of inflammation, which is central for the control of infections and the immune system.

Further studies reveal, that the ASM/ceramide system protects against staphylococcal $\alpha$-toxin-induced keratinocyte death $[71,122]$.

$S$. aureus is one of the major causes for the pathogenesis of sepsis, and although a series of appropriate antibiotics are used to clear the bacteria burden, many patients still die from fatal lung edema [123-125]. A combination of antibiotics with genetic ASM deficiency or pharmacological inhibition of the ASM successfully rescues mice from the lethality of $S$. aureus infection. This combination is sufficient to clear the bacteria and to prevent tight junction protein degradation on endothelial cell layers, as well as it prevents an uncontrolled over-activation of inflammation, which is harmful to the host immune system. A potential mechanism of the ASM/ceramide system in combination with antibiotics against $S$. aureus infection is shown in Fig. 2 . Amitriptyline, a drug routinely used to treat major depression, in combination with the appropriate antibiotics, might

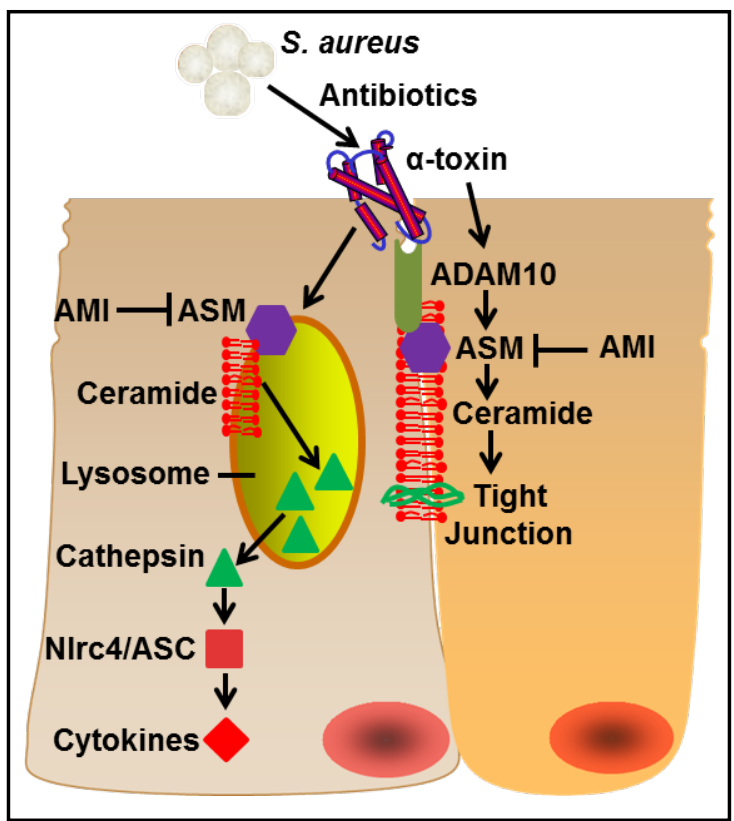

Fig. 2. Interaction of $S$. aureus with the ASM/ ceramide system. 1. Antibiotics are often insufficient to cure severe $S$. aureus, respectively MRSA infection. A-toxin induces the activation of ASM and the release of ceramide via ADAM10, which is linked to the degradation of tight junctions (right cell). However, the $\alpha$-toxin-activated ASM/ceramide system also mediates the trafficking of cathepsins from lysosomes to the cytoplasm, followed by the formation of the Nirc4/ ASC complex and the production of inflammatory cytokines. The functional ASM inhibitor amitriptyline (AMI) can prevent tight junction degradation and cytokine release. A combination of ASM inhibitors with antibiotics provides a novel approach to treat $S$. aureus and MRSA infection. be a novel therapeutic target to treat systemic $S$. aureus and most notably MRSA infections.

\section{Pathogenic mycobacteria}

Pathogenic mycobacteria, including Mycobacterium marinum (M. marinum), Mycobacterium tuberculosis (M. tuberculosis), and Mycobacterium avium (M. avium), often cause several diseases in humans, such as skin lesion, respiratory illness, fever, and tuberculosis $[126,127]$. Among these diseases, tuberculosis is a main health problem, having caused 1-5 million deaths in 2014 [128]. The host fights against pathogenic mycobacteria involve both innate and adaptive immune systems, which often wall off the pathogen enclosed in granuloma. Pathogenic mycobacteria survive and replicate in host immune cells, particularly macrophages. These pathogens prevent phagosome-lysosome fusion and evade killing, thereby persisting in the host cells.

ASM interact with the proneurotrophin receptor sortilin, which is required for the infection of M. tuberculosis in macrophages [21]. Sortilin mediates ASM trafficking from the Golgi complex into mycobacteria-containing phagosomes. Once delivered to the 


\section{Cellular Physiology Cell Physiol Biochem 2019;52:280-301 \\ \begin{tabular}{ll|l} 
and Biochemistry Published online: 28 February 2019 & C 2019 The Author(s). Published by \\
Cell Physiol Biochem Press GmbH\&Co. KG
\end{tabular} \\ Li et al.: Sphingolipids and Infections}

phagosome, ASM localizes with lysosomal-associated membrane protein (LAMP) 2 for the growth restriction and elimination of $M$. tuberculosis in bone marrow-derived macrophages. Moreover, depleting ASM with the pharmacological inhibitor desipramine increases the survival of M. tuberculosis [21]. Furthermore, ASM hydrolyzes sphingomyelin to ceramide, which is involved in the regulation of phagosome maturation, the fusion of phagosomes and lysosomes and mycobacterial killing [129-131]..

ASM deficiency protects mice against $M$. avium infection through a cell-cell fusion mechanism [132]. Interestingly, this effect is controversial with many studies showing that ASM deficiency confers susceptibility to bacterial infection in vitro and in vivo. In a recent study [132], after intravenous infection with M. avium, ASM-deficient mice survived 120 days, while the wild-type mice died between 70 and 80 days. The histology results revealed that, in ASM-deficient mice M. avium was found within minor and restricted granulomas. In contrast, wild-type mice have large granulomas with massive mycobacteria. Multinucleated giant cells containing an overload of bacteria were formed in wild-type, but not in ASMdeficient mice. ASM modulates the formation of giant cells, which provide an environment for M. avium survival and replication. The authors indicate a mechanism in which extracellular surface ASM changes the biophysical properties of the plasma membrane, therefore affecting the fusogenicity of macrophages with granulomas.

The ASM/ceramide system contributes to macrophage necrosis upon M. marinum infection [133]. Tumor necrosis factor (TNF) excessively triggers ROS generation-induced cell necrosis in macrophages infected with M. marinum, while this necrosis is prevented by the knockdown of ASM or by the long-term clinical use of desipramine, which inactivates ASM. The blocking of necrosis resulting from ceramide reduction is reproduced by the overexpression of acid ceramidase. However, the precise mechanism how the ASM/ ceramide system mediates macrophage necrosis is poorly known. The combination of gene knockdown of ASM and Cyclophilin D (CYPD), a mitochondrial matrix protein and component of the permeability transition pore, synergistically prevents the cell death of macrophages, prolongs bacterial clearance, significantly reduces bacterial burden, and consequently reverses susceptibility to $M$. marinum infection $[133,134]$. In another scenario, the infection of macrophages with $M$. tuberculosis induces cell necrosis via lysosomal membrane permeabilization and via the release of lysosomal sphingomyelinase [135]. After infection, the release of hydrolases results in a 10-fold decrease in the sphingomyelin concentration. Thus, these findings suggest that the ASM/ceramide system mediates the bioprocess of mycobacterial infection and the survival of host cells.

\section{Listeria monocytogenes (L. monocytogenes)}

L. monocytogenes-induced listeriosis is a severe disease, particularly for specific populations, such as the elderly, newborns, pregnant women, and immunocompromised patients. Innate immunity is also responsible for bactericidal activity against $L$. monocytogenes. Several studies have reported macrophage phagocytosis of L. monocytogenes and neutrophil infiltration of tissues and organs, which contribute to the clearance of the pathogen [136, 137]. However, after internalization into host cells, the pore-forming toxin listeriolysin 0 secreted from L. monocytogenes mediates lysis of the phagosomal membrane and bacterial escape into the cytoplasm, thereby causing replication in the cell $[138,139]$.

ASM-deficiency highly impairs the bactericidal capacity of mice challenged with $L$. monocytogenes due to the failure of macrophage intracellular bacteria killing [140]. The LD50 of ASM-deficient mice is lower than $10^{2}$ colony forming units (CFU), while the LD50 of wild-type is approximately $10^{4} \mathrm{CFU}$ upon i.p. infection with L. monocytogenes. ASMdeficiency induces a high bacterial load and a massive necrotic decay of the liver. The uptake of L. monocytogenes by macrophages is independent of ASM; however, ASM-deficient macrophages are unable to clear the bacteria or to restrict the replication of bacteria at later time points due to a lack of efficient phago-lysosomal fusion [129]. Instead, L. monocytogenes 


\section{Cellular Physiology Cell Physiol Biochem 2019;52:280-301 \\ \begin{tabular}{ll|l} 
and Biochemistry Published online: 28 February 2019 & C 2019 The Author(s). Published by \\
Cell Physiol Biochem Press GmbH\&Co. KG
\end{tabular} \\ Li et al.: Sphingolipids and Infections}

rapidly escape from the phagosome into the cytosol in ASM-deficient macrophages. ASMdeficiency reduces co-localization of intracellular L. monocytogenes with the late endosome/ lysosome marker Lamp1 and the listericidal proteases cathepsin D, B and L [129], while in wild-type cells ASM-generated ceramide targets and enhances the activation of the lysosomal cathepsin D [141]. Interestingly ASM does not interfere with the production of reactive oxygen intermediates upon L. monocytogenes infection, indicating that the oxidative listericidal pathway is not impaired in ASM-deficiency $[129,140]$.

\section{Pathogenic Neisseria}

Pathogenic Neisseria, including Neisseria meningitidis (N. meningitidis) and Neisseria gonorrhoeae ( $N$. gonorrhoeae), are gram-negative pathogens often recognized as commensal bacteria on human mucosal surfaces. Previous studies have demonstrated that Neisseria species employs multiple strategies to interact with various host cell receptors during the bioprocess of infection. A phase-variable outer membrane protein called opacity-associated (Opa) proteins, encoded by 4 genes in $N$. meningitidis and 11 genes in $N$. gonorrhoeae, facilitates their survival in hosts. Opa proteins interact with cellular receptors to generate a tight connection between bacteria and host cells, thus mediating bacterial invasion [142, 143].

In 1997, a study showed that ASM mediates the invasion of N. gonorrhoeae in nonphagocytic cells [62]. ASM is activated by $N$. gonorrhoeae in both epithelial cells and fibroblasts. Pharmacological inhibition of ASM by imipramine prevented the invasion of $N$. gonorrhoeae. Moreover, ASM-deficient Niemann-Pick disease type A (NPDA) cells showed reduced internalization, which is restored by the reconstitution of the enzyme.

Additional studies from the same group by using human phagocytic cells suggest that the ASM/ceramide system is critical for the invasion of $N$. gonorrhoeae via carcinoembryonic antigen-related cellular adhesion molecule (CEACAM) receptors [144]. Only the infection of $N$. gonorrhoeae-expressing virulent Opa proteins 35 and 55 leads to the activation of ASM. Pharmacological inhibition results in the reduction of bacterial internalization, whereas reconstitution of $\mathrm{C}_{16}$-ceramide completely restores bacterial internalization. The ASM inhibitor imipramine abolished the pronounced induction of JNK activity and Src-like tyrosine kinases during infection.

An additional study indicated that the ASM/ceramide system determines the internalization of Opc-expressing $N$. meningitidis into endothelial cells [145]. The integral outer membrane protein $\mathrm{Opc}$ is expressed by various virulent $N$. meningitidis lineages and mediates the adhesion and invasion of a wide range of host cells. Infection of $N$. meningitidis rapidly triggers activation of ASM and induces the formation of extracellular ceramideenriched platforms to which the bacteria adhere. The regulation of ASM upon N. meningitidis infection [145] is induced by the PC-PLC-mediated release of DAG, which is also observed in the related species $N$. gonorrhoeae [62]. ASM pharmacological inhibition, gene knockdown, or gene deficiency reduces the invasion of bacteria but does not affect the adhesion of human endothelial cells. Furthermore, the infection of different strains of $N$. meningitidis with or without Opc gene expression into endothelial cells demonstrates that Opc protein enhances the bacterial invasion driven by the ASM/ceramide system. The formation of ceramideenriched platforms upon $N$. meningitidis exposure mediates the recruiting and clustering of tyrosine kinase ErbB2 to the bacterial sites on host cells.

Taken together, these findings suggest that ASM and ceramide play a central role in the regulation of host receptor interactions with Opa or Opc proteins in the infection of human cells with pathogenic Neisseria. 


\section{Cellular Physiology Cell Physiol Biochem 2019;52:280-301 \\ \begin{tabular}{ll|l} 
and BOI: 10.33594/000000021 & C 2019 The Author(s). Published by \\
Cell Physiol Biochem Press GmbH\&Co. KG
\end{tabular} \\ Li et al.: Sphingolipids and Infections}

\section{Escherichia coli (E. coli)}

Although most E. coli are harmless and are important members of the healthy human intestine, pathogenic strains consists of diverse subtypes, including diarrheagenic E. coli and extraintestinal $E$. coli, which can cause diseases, including diarrhea, urinary tract infections, meningitis, pneumonia, and septicemia. E. coli disrupts host biophysical processes with bacteria effectors and toxins in various strategies, such as modifying host cell apoptosis, altering the actin cytoskeleton, regulating autophagy process, and targeting the multiple kinase signal transduction [146].

The ASM/ceramide system is necessary for cellular apoptosis in dendritic cells (DCs) during the course of E. coli infection [147]. The infection of human monocyte-derived immature DCs with a high numbers of $E$. coli results in cell apoptosis, which is inhibited by pharmacological inhibitor, either imipramine or D609. Importantly, the exogenous reconstitution of ceramide reverses these inhibitory effects. Compared with mature DCs, immature DCs express a significantly higher level of ASM, resulting in cell death in response to infection. Nitric oxide (NO) is a free radical and is one of the most versatile factors mediating various bioprocesses in the immune response [148], including the targeting of ASM [149]. ASM activation and immature DCs apoptosis induced by E. coli is inhibited by DETA-NO, constantly releasing NO. This mechanism of apoptosis inhibition by NO involves the activation of guanylate cyclase, the formation of cyclic guanosine monophosphate (cGMP), and the activation of G kinase. Taken together, the activation of ASM and the generation of ceramide as well as their exposure to NO depends on cGMP formation during the E. coli infection process.

Notably, recent studies have shown that the activation of ASM by platelet-activating factor-receptor (PAF-R) generates the formation of a ceramide-enriched-platform inside of a signalosome complex, including eNOS, producing NO in endothelial cells. Moreover, mechanically, the platform mediates the phosphorylation/dephosphorylation of the serine, threonine, and tyrosine residues of eNOS [150]. Further studies indicate that the inhibition of ASM decreases NO production in a NF- $\mathrm{kB}$-regulated manner and that the exogenous addition of ceramide induces the biogenesis of inducible NO synthase (iNOS) and apoptosis [151].

\section{Salmonella enterica serovar Typhimurium}

S. enterica is a rod-shaped gram-negative bacterium causing a series of infectious illnesses from localized gastroenteritis to systemic severe typhoid fever, which is a global health problem [152]. S. enterica serovar Typhimurium (S. typhimurium) is one of the moststudied types that specifically infects humans, although the mechanism of its selectivity remains unknown [153]. As a facultative intracellular pathogen, S. typhimurium promotes its invasion into host cells residing in a distinct membrane bound compartment, the Salmonellacontaining vacuole (SCV). Additionally, effector proteins of this bacterium can interfere with immune cell functions, can block the activation of the immune response and can evade the bactericidal effect.

Studies have shown that the genetic deficiency of ASM dramatically enhances the susceptibility of mice to the facultative intracellular bacterium $S$. typhimurium but not to the extracellular bacterium $S$. aureus, suggesting that ASM is involved in host defenses against intracellular pathogens [140]. Subsequent studies have also shown a key role for ASM in the killing of $S$. typhimurium in macrophages [154]. The reduction of bacteria killing in macrophages is dependent on ASM. This study also showed that the activation of ASM in S. typhimurium elimination is linked to NADPH-mediated ROS release, consistent with the studies of ASM regulating host defense against Pseudomonas [29]. The supernatant of infected macrophage contained a significantly increased ASM enzymatic activity compared with the uninfected group, which indicates that $S$. typhimurium infection leads to the redistribution of ASM from the cytosol to the cell membrane or to the extracellular environment. This 


\section{Cellular Physiology Cell Physiol Biochem 2019;52:280-301 \\ \begin{tabular}{ll|l} 
and BOI: 10.33594/000000021 & C 2019 The Author(s). Published by \\
Cell Physiol Biochem Press GmbH\&Co. KG
\end{tabular} \\ Li et al.: Sphingolipids and Infections}

trafficking of ASM does not only exist in S. typhimurium, as E. coli induces a similar effect. According to the extracellular translocation of ASM in response to different bacteria species, the trafficking of ASM may be required for bactericidal activity against various types of pathogenic bacteria.

\section{Propionibacterium acnes (P. acnes)}

P. acnes, an opportunistic pathogen, is critically associated with the pathogenesis of acne vulgaris, which is the most prevalent skin disease, persisting by up to $85 \%$ among individuals 12-24 years old $[155,156]$. The P. acnes genome encodes the Christie-Atkins-Munch-Petersen (CAMP) factor, which binds to immunoglobulins $\mathrm{G}$ and $\mathrm{M}$ and acts as a pore-forming toxin. In addition, $P$. acnes induces the release of inflammatory cytokines involved in the activation of Toll-like receptor 4 (TLR-4), thereby manipulating the host immune response. The invasive and chronic implant infections are closely related to the biofilm formation of $P$. acnes [157].

ASM is involved in P. acnes virulence-induced inflammation [158]. The co-culture of P. acnes with HaCaT keratinocytes and RAW264.7 macrophages stimulates the secretion of ASM into the culture supernatant. P. acnes induces cell death in host cells, which is blocked by addition of the ASM inhibitor desipramine in vitro. Intradermal injection of ICR mice with bacteria significantly increases ASM expression. Host ASM is responsible for recruiting of $\mathrm{CD} 11 \mathrm{~b}^{+}$macrophages. Importantly, the combination of CAMP factor vaccination with antiASM IgG injection alleviates bacteria-induced inflammation, indicating a cross talk between CAMP factor and ASM. The results indicate a mechanism that $P$. acnes resists against phagocytosis by taking advantage of the host L-ASM. Additionally, desipramine or other ASM inhibitors may be potential therapeutic compounds for treating the cytotoxicity of $P$. acnes infection.

\section{Lipopolysaccharide}

Many pathogenic bacteria initiate infection and mediate their toxicity to hosts by producing virulence factors called toxins. Lipopolysaccharide (LPS), a main component of the gram-negative bacteria cell membrane, acts as a most efficacious microbial intermediator, which is responsible for the pathogenesis of sepsis and septic shock $[159,160]$. LPS provokes intense proinflammatory and microbicidal activation of host cells, including macrophages, followed by a release of cytokines, such as TNF- $\alpha$, interleukins, and NO. The sudden release of a significant amount of LPS into the blood stream is detrimental, often causing endothelial injury, tissue hypoperfusion, and refractory shock. Several receptors of LPS have been identified: CD14-MD2-TLR4 molecules, $\beta 2$-integrins, scavenger receptors and serum LPSbinding protein [161]. Studies have shown that cellular exposure to LPS induces activation of ASM and a release of ceramide in dendritic cells [147], macrophages [162], monocytes [163], lung tissues [164], intestinal mucosa [165] and serum [166].

LPS activates ASM not only within the cells but also stimulates the extracellular secretion into the blood and intestines in vivo $[165,166]$. Mechanically, the activation of the ASM/ceramide system by LPS is inhibited by immune-modulating messenger NO through the formation of cGMP and through the activation of the cGMP-dependent protein kinase, therefore inhibiting dendritic cell death [147]. Inhibiting the NF- $\mathrm{BB}$ pathway by a cell-penetrating peptide sufficiently suppresses ASM activation. The ceramide-mediated production of TNF- $\alpha$, IL-6, CXC chemokine CXCL8, and MCP-1, as key regulators of inflammation, is also reduced upon NF- $\kappa B$ inhibition [164]. Studies have also shown that the effect of LPS on ASM activation involves the production of IL-1 $\beta$ and TNF- $\alpha[165,166]$. Vice versa, ASM activation by LPS is required for the release of TNF- $\alpha$ [163]. Exposure to LPS leads to the generation of ceramide-enriched microdomain assembly and the activation of 


\section{Cellular Physiology Cell Physiol Biochem 2019;52:280-301 \\ \begin{tabular}{ll|l} 
and Biochemistry $10.33594 / 000000021$ & Published online: 28 February 2019 & 2019 The Author(s). Published by \\
Cell Physiol Biochem Press GmbH\&Co. KG
\end{tabular} \\ Li et al.: Sphingolipids and Infections}

the TLR4 receptor, mediating the phosphorylation of atypical PKC- $\zeta$ and the activation of the MAPK family, composed of ERK 1/2, p38, and JNK/SAPK.

In conclusion, these findings suggest that the ASM/ceramide system modulates the inflammatory response and the death of host cells upon LPS challenge.

\section{Summary}

Although multiple studies implicate the ASM/ceramide system in bacteria-host interactions, mechanisms regarding the roles and regulations of ASM in cellular processes still require further definition. Whether bacteria directly regulate ASM activity, trafficking, and localization or indirectly regulate other cellular pathways remains to be characterized. The role of lysosomal ASM in bacterial killing or immune evasion as well as the mechanisms of secretion of ASM on the plasma membrane during bacterial internalization requires further characterization. The subsequent biological consequences of ASMgenerated ceramide in different parts of the cell also remain unclear at present.

Amitriptyline, a tricyclic antidepressant (TCA), is a drug used for the treatment of a number of mental diseases. Importantly, amitriptyline is recognized as a functional ASM inhibitor [167]. The application of amitriptyline to cystic fibrosis mice normalizes pulmonary ceramide levels and abolishes pathological outcome, including susceptibility to infection [70]. Moreover, the inhibition of ASM by amitriptyline and other tricyclic antidepressants prevents $P$. aeruginosa infection and pulmonary inflammation in mice and in patients with cystic fibrosis [168-170]. Importantly, clinical trials indicate that treatment of cystic fibrosis patients with amitriptyline results in a decrease in ceramide levels in lung cells and an increase in lung function $[171,172]$. With regard to ASM inhibitors treating bacterial infections, the dose and administration in experiments and clinical trials are shown in Table 2. Amitriptyline may be a novel, safe and effective medicine to treat CF patients.

ASM is critical in the regulation of host interactions with bacteria, including P. aeruginosa, $S$. aureus, mycobacteria, $L$ monocytogenes, Neisseria spec., E. coli, $S$. enterica, $P$. acnes and bacterial toxins or LPS. Fig. 3 shows the potential role of the ASM/ceramide system in bacterial infections. The infection of mammalian cells with bacteria triggers the activation of ASM and the secretion of ASM onto membranes as well as the extracellular

Table 2. ASM inhibitors in treating infection or infection-related diseases in human or mice

\begin{tabular}{lccc}
\hline ASM inhibitors & Usage & Species & References \\
\hline Amitryptyline & $4 \mathrm{mg} / \mathrm{L}$ in saline, inhalation & Mice & {$[168]$} \\
& $10 \mathrm{mg} / \mathrm{kg}$, intraperitoneal injection & Mice & {$[87,95]$} \\
& $120 \mathrm{mg} / \mathrm{L}$ in drinking water & Mice & {$[79,95]$} \\
& $25,50,75 \mathrm{mg} / \mathrm{d}$, oral & Human & {$[171,172]$} \\
Fluoxetine & $4.5 \mathrm{mg} / \mathrm{L}$ in saline, inhalation & Mice & {$[168]$} \\
& $120 \mathrm{mg} / \mathrm{L}$ in drinking water & Mice & {$[95]$} \\
Trimipramine & $12.5 \mathrm{mg} / \mathrm{L}$ in saline, inhalation & Mice & {$[168]$} \\
Sertraline & $35 \mathrm{mg} / \mathrm{L}$ in saline, inhalation & Mice & {$[168]$} \\
Desipramine & $9 \mathrm{mg} / \mathrm{L}$ in saline, inhalation & Mice & {$[168]$} \\
Chlorprothixene & $8 \mathrm{mg} / \mathrm{L}$ in saline, inhalation & Mice & {$[168]$} \\
\hline
\end{tabular}

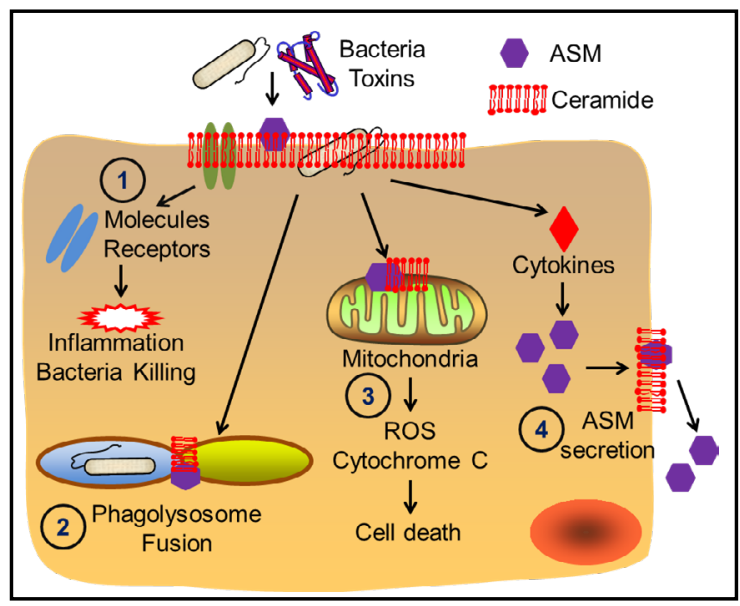

Fig. 3. ASM/ceramide system in bacteria-host interactions. 1. Bacteria induce activation of ASM and release of ceramide, which recruits signaling molecules and receptors, such as NADPH oxidase, ErbB2, JNK, CFTR, CD95, JNK, and p38 kinase, therefore modulating ROS generation, cytokine release, host cell death, and bacterial killing. 2. ASM-generated ceramide recruits molecules and receptors and mediates bacterial internalization. In addition, the ASM/ceramide system is needed for the fusion of phagolysosomes. 3. The ASM/ceramide system is involved in mitochondriainduced cell death upon infection. 4. Inflammatory cytokines stimulate the secretion of ASM from the cytoplasm to the extracellular environment. 


\section{Cellular Physiology Cell Physiol Biochem 2019;52:280-301 \begin{tabular}{ll|l} 
and Biochemistry & $\begin{array}{l}\text { DOl: 10.33594/000000021 } \\
\text { Published online: } 28 \text { February } 2019\end{array}$ & $\begin{array}{l}\text { O } 2019 \text { The Author(s). Published by } \\
\text { Cell Physiol Biochem Press GmbH\&Co. KG }\end{array}$ \\
\cline { 2 - 3 }
\end{tabular} \\ Li et al.: Sphingolipids and Infections}

environment. ASM-generated ceramide initiates lipid domain organization, thereby mediating interactions of bacteria with host cells. ASM facilitates the activation of NADPH oxidases, which involves the generation of superoxide, responsible for bacteria killing and regulating cell apoptosis. Ceramide platforms also mediate the internalization of bacteria into host cells. Moreover, ASM-generated ceramide modifies the membrane biophysical properties and recruits receptor molecules, thereby modulating the fusion of phagosomes and lysosomes. In addition, ASM influences cytokine release and inflammatory responses. Taken together, although the detailed mechanisms of the ASM/ceramide system acting on bacterial infection remain unknown, strong evidence shows the central role of this system in bacteria-host interactions. Targeting the ASM/ceramide system might be a novel and potential therapeutic approach for treating bacterial infection.

\section{Disclosure Statement}

The authors declare that no conflicts of interest exist.

\section{References}

1 Heung LJ, Luberto C, Del Poeta M: Role of sphingolipids in microbial pathogenesis. Infect Immun 2006;74:28-39.

2 McQuiston TJ, Haller C, Del Poeta M: Sphingolipids as targets for microbial infections. Mini Rev Med Chem 2006;6:671-680.

3 Slotte JP, Ramstedt B: The functional role of sphingomyelin in cell membranes. Eur J Lipid Sci Technol 2007;109:977-981.

4 Henry B, Ziobro R, Becker KA, Kolesnick R, Gulbins E: Acid sphingomyelinase. Handb Exp Pharmacol 2013;77-88.

5 da Veiga Pereira L, Desnick RJ, Adler DA, Disteche CM, Schuchman EH: Regional assignment of the human acid sphingomyelinase gene (SMPD1) by PCR analysis of somatic cell hybrids and in situ hybridization to 11p15.1----p15.4. Genomics 1991;9:229-234.

6 Schuchman EH, Levran O, Pereira LV, Desnick RJ: Structural organization and complete nucleotide sequence of the gene encoding human acid sphingomyelinase (SMPD1). Genomics 1992;12:197-205.

7 Schuchman EH, Suchi M, Takahashi T, Sandhoff K, Desnick RJ: Human acid sphingomyelinase. Isolation, nucleotide sequence and expression of the full-length and alternatively spliced cDNAs. J Biol Chem 1991;266:8531-8539.

8 Quintern LE, Schuchman EH, Levran O, Suchi M, Ferlinz K, Reinke H, Sandhoff K, Desnick RJ: Isolation of cDNA clones encoding human acid sphingomyelinase: occurrence of alternatively processed transcripts. EMBO J 1989;8:2469-2473.

9 Newrzella D, Stoffel W: Molecular cloning of the acid sphingomyelinase of the mouse and the organization and complete nucleotide sequence of the gene. Biol Chem Hoppe Seyler 1992;373:1233-1238.

10 Xiong ZJ, Huang J, Poda G, Pomès RG, Privé GG: Structure of Human Acid Sphingomyelinase Reveals the Role of the Saposin Domain in Activating Substrate Hydrolysis. J Mol Biol 2016;428:3026-3042.

11 Gorelik A, Illes K, Heinz LX, Superti-Furga G, Nagar B: Crystal structure of mammalian acid sphingomyelinase. Nat Commun 2016;7:12196.

12 Schuchman EH: The pathogenesis and treatment of acid sphingomyelinase-deficient Niemann-Pick disease. J Inherit Metab Dis 2007;30:654-663.

13 McGovern MM, Aron A, Brodie SE, Desnick RJ, Wasserstein MP: Natural history of Type A Niemann-Pick disease: possible endpoints for therapeutic trials. Neurology 2006;66:228-232.

14 McGovern MM, Wasserstein MP, Giugliani R, Bembi B, Vanier MT, Mengel E, Brodie SE, Mendelson D, Skloot G, Desnick RJ, Kuriyama N, Cox GF: A prospective, cross-sectional survey study of the natural history of Niemann-Pick disease type B. Pediatrics 2008;122:e341-e349.

- 15 Fowler S: Lysosomal localization of sphingomyelinase in rat liver. Biochim Biophys Acta 1969;191:481-484. 


\section{Cellular Physiology Cell Physiol Biochem 2019;52:280-301 \begin{tabular}{ll|l} 
and Biochemistry & DOl: 10.33594/000000021 & P 2019 The Author(s). Published by \\
\cline { 2 - 3 } & Cell Physiol Biochem Press GmbH\&Co. KG
\end{tabular} \\ Li et al.: Sphingolipids and Infections}

- 16 Schissel SL, Jiang X, Tweedie-Hardman J, Jeong T, Camejo EH, Najib J, Rapp JH, Williams KJ, Tabas I: Secretory sphingomyelinase, a product of the acid sphingomyelinase gene, can hydrolyze atherogenic lipoproteins at neutral pH. Implications for atherosclerotic lesion development. J Biol Chem 1998;273:2738-2746.

17 Schissel SL, Keesler GA, Schuchman EH, Williams KJ, Tabas I: The cellular trafficking and zinc dependence of secretory and lysosomal sphingomyelinase, two products of the acid sphingomyelinase gene. J Biol Chem 1998;273:18250-18259.

18 Ferlinz K, Hurwitz R, Moczall H, Lansmann S, Schuchman EH, Sandhoff K: Functional characterization of the N-glycosylation sites of human acid sphingomyelinase by site-directed mutagenesis. Eur J Biochem 1997;243:511-517.

19 Ni X, Morales CR: The lysosomal trafficking of acid sphingomyelinase is mediated by sortilin and mannose 6-phosphate receptor. Traffic 2006;7:889-902.

20 Takahashi I, Takahashi T, Mikami T, Komatsu M, Ohura T, Schuchman EH, Takada G: Acid sphingomyelinase: relation of 93lysine residue on the ratio of intracellular to secreted enzyme activity. Tohoku J Exp Med 2005;206:333-340.

21 Vázquez CL, Rodgers A, Herbst S, Coade S, Gronow A, Guzman CA, Wilson MS, Kanzaki M, Nykjaer A, Gutierrez MG: The proneurotrophin receptor sortilin is required for Mycobacterium tuberculosis control by macrophages. Sci Rep 2016;6:29332.

22 Wähe A, Kasmapour B, Schmaderer C, Liebl D, Sandhoff K, Nykjaer A, Griffiths G, Gutierrez MG: Golgito-phagosome transport of acid sphingomyelinase and prosaposin is mediated by sortilin. J Cell Sci 2010;123:2502-2511.

23 Kornhuber J, Rhein C, Müller CP, Muhle C: Secretory sphingomyelinase in health and disease. Biol Chem 2015;396:707-736.

24 Edelmann B, Bertsch U, Tchikov V, Winoto-Morbach S, Perrotta C, Jakob M, Adam-Klages S, Kabelitz D, Schutze S: Caspase-8 and caspase-7 sequentially mediate proteolytic activation of acid sphingomyelinase in TNF-R1 receptosomes. EMBO J 2011;30:379-394.

25 Jenkins RW, Canals D, Idkowiak-Baldys J, Simbari F, Roddy P, Perry DM, Kitatani K, Luberto C, Hannun YA: Regulated secretion of acid sphingomyelinase: implications for selectivity of ceramide formation. J Biol Chem 2010;285:35706-35718.

26 Jenkins RW, Idkowiak-Baldys J, Simbari F, Canals D, Roddy P, Riner CD, Clarke CJ, Hannun YA: A novel mechanism of lysosomal acid sphingomyelinase maturation: requirement for carboxyl-terminal proteolytic processing. J Biol Chem 2011;286:3777-3788.

27 Managò A, Becker KA, Carpinteiro A, Wilker B, Soddemann M, Seitz AP, Edwards MJ, Grassmé H, Szabò I, Gulbins E: Pseudomonas aeruginosa pyocyanin induces neutrophil death via mitochondrial reactive oxygen species and mitochondrial acid sphingomyelinase. Antioxid Redox Signal 2015;22:1097-1110.

28 Li X, Gulbins E, Zhang Y: Oxidative Stress Triggers Ca-Dependent Lysosome Trafficking and Activation of Acid Sphingomyelinase. Cell Physiol Biochem 2012;30:815-826.

29 Zhang Y, Li X, Carpinteiro A, Gulbins E: Acid sphingomyelinase amplifies redox signaling in Pseudomonas aeruginosa-induced macrophage apoptosis. J Immunol 2008;181:4247-4254.

30 Grammatikos G, Teichgräber V, Carpinteiro A, Trarbach T, Weller M, Hengge UR, Gulbins E: Overexpression of acid sphingomyelinase sensitizes glioma cells to chemotherapy. Antioxid Redox Signal 2007;9:14491456.

31 Peng H, Li C, Kadow S, Henry BD, Steinmann J, Becker KA, Riehle A, Beckmann N, Wilker B, Li P-L, Pritts T, Edwards MJ, Zhang Y, Gulbins E, Grassmé H: Acid sphingomyelinase inhibition protects mice from lung edema and lethal Staphylococcus aureus sepsis. J Mol Med (Berl) 2015;93:675-689.

32 Lang PA, Schenck M, Nicolay JP, Becker JU, Kempe DS, Lupescu A, Koka S, Eisele K, Klarl BA, Rubben H, Schmid KW, Mann K, Hildenbrand S, Hefter H, Huber SM, Wieder T, Erhardt A, Häussinger D, Gulbins E, Lang F: Liver cell death and anemia in Wilson disease involve acid sphingomyelinase and ceramide. Nat Med 2007;13:164-170.

33 Dumitru CA, Gulbins E: TRAIL activates acid sphingomyelinase via a redox mechanism and releases ceramide to trigger apoptosis. Oncogene 2006;25:5612-5625.

34 Boini KM, Zhang C, Xia M, Han W-Q, Brimson C, Poklis JL, Li P-L: Visfatin-induced lipid raft redox signaling platforms and dysfunction in glomerular endothelial cells. Biochim Biophys Acta 2010;1801:1294-1304. 


\section{Cellular Physiology Cell Physiol Biochem 2019;52:280-301 \begin{tabular}{ll|l} 
and Biochemistry & DOl: 10.33594/000000021 & P 2019 The Author(s). Published by \\
\cline { 2 - 3 } & Cell Physiol Biochem Press GmbH\&Co. KG
\end{tabular} \\ Li et al.: Sphingolipids and Infections}

35 Qiu H, Edmunds T, Baker-Malcolm J, Karey KP, Estes S, Schwarz C, Hughes H, Van Patten SM: Activation of human acid sphingomyelinase through modification or deletion of C-terminal cysteine. J Biol Chem 2003;278:32744-32752.

36 Jenkins RW, Canals D, Hannun YA: Roles and regulation of secretory and lysosomal acid sphingomyelinase. Cell Signal 2009;21:836-846.

37 Kornhuber J, Müller CP, Becker KA, Reichel M, Gulbins E: The ceramide system as a novel antidepressant target. Trends Pharmacol Sci 2014;35:293-304.

38 Hannun YA, Obeid LM: Many ceramides. J Biol Chem 2011;286:27855-27862.

39 Hannun YA, Obeid LM: Principles of bioactive lipid signalling: lessons from sphingolipids. Nat Rev Mol Cell Biol 2008;9:139-150.

40 Perry DK, Carton J, Shah AK, Meredith F, Uhlinger DJ, Hannun YA: Serine palmitoyltransferase regulates de novo ceramide generation during etoposide-induced apoptosis. J Biol Chem 2000;275:9078-9084.

41 Merrill AH Jr: De novo sphingolipid biosynthesis: a necessary, but dangerous, pathway. J Biol Chem 2002;277:25843-25846.

42 Verkleij AJ, Zwaal RF, Roelofsen B, Comfurius P, Kastelijn D, van Deenen LL: The asymmetric distribution of phospholipids in the human red cell membrane. A combined study using phospholipases and freeze-etch electron microscopy. Biochim Biophys Acta 1973;323:178-193.

43 van Meer G, Voelker DR, Feigenson GW: Membrane lipids: where they are and how they behave. Nat Rev Mol Cell Biol 2008;9:112-124.

44 Wu Y, Gulbins E, Grassmé H: Crosstalk Between Sphingomyelinases and Reactive Oxygen Species in Mycobacterial Infection. Antioxid Redox Signal 2017; DOI:10.1089/ars.2017.7050.

45 Grösch S, Schiffmann S, Geisslinger G: Chain length-specific properties of ceramides. Prog Lipid Res 2012;51:50-62.

46 Castro BM, Prieto M, Silva LC: Ceramide: a simple sphingolipid with unique biophysical properties. Prog Lipid Res 2014;54:53-67.

47 Simons K, Ikonen E: Functional rafts in cell membranes. Nature 1997;387:569-572.

48 Brown DA, London E: Functions of lipid rafts in biological membranes. Annu Rev Cell Dev Biol 1998;14:111-136.

49 Kolesnick RN, Goñi FM, Alonso A: Compartmentalization of ceramide signaling: physical foundations and biological effects. J Cell Physiol 2000;184:285-300.

50 Gulbins E, Walter S, Becker KA, Halmer R, Liu Y, Reichel M, Edwards MJ, Müller CP, Fassbender K, Kornhuber J: A central role for the acid sphingomyelinase/ceramide system in neurogenesis and major depression. J Neurochem 2015;134:183-192.

51 Zhang Y, Li X, Becker KA, Gulbins E: Ceramide-enriched membrane domains-structure and function. Biochim Biophys Acta 2009;1788:178-183.

52 Grassmé H, Jekle A, Riehle A, Schwarz H, Berger J, Sandhoff K, Kolesnick R, Gulbins E: CD95 signaling via ceramide-rich membrane rafts. J Biol Chem 2001;276:20589-20596.

53 Cremesti A, Paris F, Grassmé H, Holler N, Tschopp J, Fuks Z, Gulbins E, Kolesnick R: Ceramide enables fas to cap and kill. J Biol Chem 2001;276:23954-23961.

54 Grassmé H, Schwarz H, Gulbins E: Molecular mechanisms of ceramide-mediated CD95 clustering. Biochem Biophys Res Commun 2001;284:1016-1030.

55 Grassmé H, Cremesti A, Kolesnick R, Gulbins E: Ceramide-mediated clustering is required for CD95-DISC formation. Oncogene 2003;22:5457-5470.

56 Abdel Shakor AB, Kwiatkowska K, Sobota A: Cell surface ceramide generation precedes and controls Fc $\gamma$ RII clustering and phosphorylation in rafts. J Biol Chem 2004;279:36778-36787.

57 Grassmé H, Jendrossek V, Bock J, Riehle A, Gulbins E: Ceramide-rich membrane rafts mediate CD40 clustering. J Immunol 2002;168:298-307.

58 Göggel R, Winoto-Morbach S, Vielhaber G, Imai Y, Lindner K, Brade L, Brade H, Ehlers S, Slutsky AS, Schutze S, Gulbins E, Uhlig S: PAF-mediated pulmonary edema: a new role for acid sphingomyelinase and ceramide. Nat Med 2004;10:155-160.

59 Avota E, Gulbins E, Schneider-Schaulies S: DC-SIGN mediated sphingomyelinase-activation and ceramide generation is essential for enhancement of viral uptake in dendritic cells. PLoS Pathog 2011;7:e1001290. 


\section{Cellular Physiology Cell Physiol Biochem 2019;52:280-301 \begin{tabular}{ll|l} 
and Biochemistry & $\begin{array}{l}\text { DOl: 10.33594/000000021 } \\
\text { Published online: } 28 \text { February } 2019\end{array}$ & $\begin{array}{l}\text { O } 2019 \text { The Author(s). Published by } \\
\text { Cell Physiol Biochem Press GmbH\&Co. KG }\end{array}$ \\
\cline { 2 - 3 }
\end{tabular} \\ Li et al.: Sphingolipids and Infections}

60 Gassert E, Avota E, Harms H, Krohne G, Gulbins E, Schneider-Schaulies S: Induction of membrane ceramides: a novel strategy to interfere with $\mathrm{T}$ lymphocyte cytoskeletal reorganisation in viral immunosuppression. PLoS Pathog 2009;5:e1000623.

61 Grassmé H, Riehle A, Wilker B, Gulbins E: Rhinoviruses infect human epithelial cells via ceramide-enriched membrane platforms. J Biol Chem 2005;280:26256-26262.

62 Grassmé H, Gulbins E, Brenner B, Ferlinz K, Sandhoff K, Harzer K, Lang F, Meyer TF: Acidic sphingomyelinase mediates entry of $N$. gonorrhoeae into nonphagocytic cells. Cell 1997;91:605-615.

63 Grassmé H, Jendrossek V, Riehle A, von Kürthy G, Berger J, Schwarz H, Weller M, Kolesnick R, Gulbins E: Host defense against Pseudomonas aeruginosa requires ceramide-rich membrane rafts. Nat Med 2003;9:322-330.

64 Lacour S, Hammann A, Grazide S, Lagadic-Gossmann D, Athias A, Sergent O, Laurent G, Gambert P, Solary E, Dimanche-Boitrel MT: Cisplatin-induced CD95 redistribution into membrane lipid rafts of HT29 human colon cancer cells. Cancer Res 2004;64:3593-3598.

65 Rotolo J, Stancevic B, Zhang J, Hua G, Fuller J, Yin X, Haimovitz-Friedman A, Kim K, Qian M, Cardó-Vila M, Fuks Z, Pasqualini R, Arap W, Kolesnick R: Anti-ceramide antibody prevents the radiation gastrointestinal syndrome in mice. J Clin Invest 2012;122:1786-1790.

66 Zhang Y, Mattjus P, Schmid PC, Dong Z, Zhong S, Ma WY, Brown RE, Bode AM, Schmid HH, Dong Z: Involvement of the acid sphingomyelinase pathway in UVA-induced apoptosis. J Biol Chem 2001;276:11775-11782.

67 Kashkar H, Wiegmann K, Yazdanpanah B, Haubert D, Krönke M: Acid sphingomyelinase is indispensable for UV light-induced Bax conformational change at the mitochondrial membrane. J Biol Chem 2005;280:20804-20813.

68 Hueber A-0, Bernard A-M, Hérincs Z, Couzinet A, He H-T: An essential role for membrane rafts in the initiation of Fas/CD95-triggered cell death in mouse thymocytes. EMBO Rep 2002;3:190-196.

69 Garcia-Ruiz C, Mato JM, Vance D, Kaplowitz N, Fernández-Checa JC: Acid sphingomyelinase-ceramide system in steatohepatitis: a novel target regulating multiple pathways. J Hepatol 2015;62:219-233.

70 Teichgräber V, Ulrich M, Endlich N, Riethmüller J, Wilker B, De Oliveira-Munding CCao, van Heeckeren AM, Barr ML, von Kürthy G, Schmid KW, Weller M, Tümmler B, Lang F, Grassmé H, Döring G, Gulbins E: Ceramide accumulation mediates inflammation, cell death and infection susceptibility in cystic fibrosis. Nat Med 2008;14:382-391.

71 Brauweiler AM, Bin L, Kim BE, Oyoshi MK, Geha RS, Goleva E, Leung DYM: Filaggrin-dependent secretion of sphingomyelinase protects against staphylococcal $\alpha$-toxin-induced keratinocyte death. J Allergy Clin Immunol 2013;131:421-427.e1-2.

72 Ranganath P, Matta D, Bhavani GS, Wangnekar S, Jain JMN, Verma IC, Kabra M, Puri RD, Danda S, Gupta N, Girisha KM, Sankar VH, Patil SJ, Ramadevi AR, Bhat M, Gowrishankar K, Mandal K, Aggarwal S, Tamhankar PM, Tilak P, et al.: Spectrum of SMPD1 mutations in Asian-Indian patients with acid sphingomyelinase (ASM)-deficient Niemann-Pick disease. Am J Med Genet A 2016;170:2719-2730.

73 Aykut A, Karaca E, Onay H, Ucar SK, Coker M, Cogulu O, Ozkinay F: Analysis of the sphingomyelin phosphodiesterase 1 gene (SMPD1) in Turkish Niemann-Pick disease patients: mutation profile and description of a novel mutation. Gene 2013;526:484-486.

74 Carpinteiro A, Beckmann N, Seitz A, Hessler G, Wilker B, Soddemann M, Helfrich I, Edelmann B, Gulbins E, Becker KA: Role of Acid Sphingomyelinase-Induced Signaling in Melanoma Cells for Hematogenous Tumor Metastasis. Cell Physiol Biochem 2016;38:1-14.

75 Carpinteiro A, Becker KA, Japtok L, Hessler G, Keitsch S, Požgajovà M, Schmid KW, Adams C, Müller S, Kleuser B, Edwards MJ, Grassmé H, Helfrich I, Gulbins E: Regulation of hematogenous tumor metastasis by acid sphingomyelinase. EMBO Mol Med 2015;7:714-734.

76 Gulbins A, Grassmé H, Hoehn R, Kohnen M, Edwards MJ, Kornhuber J, Gulbins E: Role of Janus-Kinases in Major Depressive Disorder. Neurosignals 2016;24:71-80.

- 77 Gulbins A, Grassmé H, Hoehn R, Wilker B, Soddemann M, Kohnen M, Edwards MJ, Kornhuber J, Gulbins E: Regulation of Neuronal Stem Cell Proliferation in the Hippocampus by Endothelial Ceramide. Cell Physiol Biochem 2016;39:790-801.

78 Grassmé H, Jernigan PL, Hoehn RS, Wilker B, Soddemann M, Edwards MJ, Müller CP, Kornhuber J, Gulbins E: Inhibition of Acid Sphingomyelinase by Antidepressants Counteracts Stress-Induced Activation of P38Kinase in Major Depression. Neurosignals 2015;23:84-92. 


\section{Cellular Physiology Cell Physiol Biochem 2019;52:280-301 \begin{tabular}{ll|l} 
and Biochemistry & DOl: 10.33594/000000021 & P 2019 The Author(s). Published by \\
\cline { 2 - 3 } & Cell Physiol Biochem Press GmbH\&Co. KG
\end{tabular} \\ Li et al.: Sphingolipids and Infections}

79 Gulbins E, Palmada M, Reichel M, Lüth A, Bohmer C, Amato D, Müller CP, Tischbirek CH, Groemer TW, Tabatabai G, Becker KA, Tripal P, Staedtler S, Ackermann TF, van Brederode J, Alzheimer C, Weller M, Lang UE, Kleuser B, Grassmé H, Kornhuber J: Acid sphingomyelinase-ceramide system mediates effects of antidepressant drugs. Nat Med 2013;19:934-938.

80 Deevska GM, Sunkara M, Morris AJ, Nikolova-Karakashian MN: Characterization of secretory sphingomyelinase activity, lipoprotein sphingolipid content and LDL aggregation in ldlr-/- mice fed on a high-fat diet. Biosci Rep 2012;32:479-490.

81 Kobayashi K, Nagata E, Sasaki K, Harada-Shiba M, Kojo S, Kikuzaki H: Increase in secretory sphingomyelinase activity and specific ceramides in the aorta of apolipoprotein E knockout mice during aging. Biol Pharm Bull 2013;36:1192-1196.

82 Talwalkar JS, Murray TS: The Approach to Pseudomonas aeruginosa in Cystic Fibrosis. Clin Chest Med 2016;37:69-81.

83 Ramírez-Estrada S, Borgatta B, Rello J: Pseudomonas aeruginosa ventilator-associated pneumonia management. Infect Drug Resist 2016;9:7-18.

84 Kowalski MP, Pier GB: Localization of cystic fibrosis transmembrane conductance regulator to lipid rafts of epithelial cells is required for Pseudomonas aeruginosa-induced cellular activation. J Immunol 2004;172:418-425.

85 Kuzmenko DI, Klimentyeva TK: Role of Ceramide in Apoptosis and Development of Insulin Resistance. Biochemistry. Biochemistry (Mosc) 2016;81:913-927.

86 Saddoughi SA, Ogretmen B: Diverse functions of ceramide in cancer cell death and proliferation. Adv Cancer Res 2013;117:37-58.

87 Reinehr R, Becker S, Braun J, Eberle A, Grether-Beck S, Häussinger D: Endosomal acidification and activation of NADPH oxidase isoforms are upstream events in hyperosmolarity-induced hepatocyte apoptosis. J Biol Chem 2006;281:23150-23166.

88 Grassmé H, Kirschnek S, Riethmueller J, Riehle A, von Kürthy G, Lang F, Weller M, Gulbins E: CD95/CD95 ligand interactions on epithelial cells in host defense to Pseudomonas aeruginosa. Science 2000;290:527530.

89 Yu H, Zeidan YH, Wu BX, Jenkins RW, Flotte TR, Hannun YA, Virella-Lowell I: Defective acid sphingomyelinase pathway with Pseudomonas aeruginosa infection in cystic fibrosis. Am J Respir Cell Mol Biol 2009;41:367-375.

90 Schultz MJ, Rijneveld AW, Florquin S, Edwards CK, Dinarello CA, van der Poll T: Role of interleukin-1 in the pulmonary immune response during Pseudomonas aeruginosa pneumonia. Am J Physiol Lung Cell Mol Physiol 2002;282:L285-290.

91 Khan MA, Farahvash A, Douda DN, Licht J-C, Grasemann H, Sweezey N, Palaniyar N: JNK Activation Turns on LPS- and Gram-Negative Bacteria-Induced NADPH Oxidase-Dependent Suicidal NETosis. Sci Rep 2017;7:3409.

92 Vareechon C, Zmina SE, Karmakar M, Pearlman E, Rietsch A: Pseudomonas aeruginosa Effector ExoS Inhibits ROS Production in Human Neutrophils. Cell Host Microbe 2017;21:611-618.e615.

93 Sharma P, Guha S, Garg P, Roy S: Differential expression of antimicrobial peptides in corneal infection and regulation of antimicrobial peptides and reactive oxygen species by type III secretion system of Pseudomonas aeruginosa. Pathog Dis 2018; DOI:10.1093/femspd/fty001.

94 Hauser AR: The type III secretion system of Pseudomonas aeruginosa: infection by injection. Nature reviews. Microbiology 2009;7:654-665.

95 Grassmé H, Henry B, Ziobro R, Becker KA, Riethmüller J, Gardner A, Seitz AP, Steinmann J, Lang S, Ward C, Schuchman EH, Caldwell CC, Kamler M, Edwards MJ, Brodlie M, Gulbins E: $\beta 1$-Integrin Accumulates in Cystic Fibrosis Luminal Airway Epithelial Membranes and Decreases Sphingosine, Promoting Bacterial Infections. Cell Host Microbe 2017;21:707-718.e708.

96 Pewzner-Jung Y, Tavakoli Tabazavareh S, Grassmé H, Becker KA, Japtok L, Steinmann J, Joseph T, Lang S, Tuemmler B, Schuchman EH, Lentsch AB, Kleuser B, Edwards MJ, Futerman AH, Gulbins E: Sphingoid long chain bases prevent lung infection by Pseudomonas aeruginosa. EMBO Mol Med 2014;6:1205-1214.

97 Tavakoli Tabazavareh S, Seitz A, Jernigan P, Sehl C, Keitsch S, Lang S, Kahl BC, Edwards M, Grassmé H, Gulbins E, Becker KA: Lack of Sphingosine Causes Susceptibility to Pulmonary Staphylococcus Aureus Infections in Cystic Fibrosis. Cell Physiol Biochem 2016;38:2094-2102. 


\section{Cellular Physiology Cell Physiol Biochem 2019;52:280-301 \begin{tabular}{ll|l} 
and Biochemistry & $\begin{array}{l}\text { DOl: 10.33594/000000021 } \\
\text { Published online: } 28 \text { February } 2019\end{array}$ & $\begin{array}{l}\text { O } 2019 \text { The Author(s). Published by } \\
\text { Cell Physiol Biochem Press GmbH\&Co. KG }\end{array}$ \\
\cline { 2 - 3 }
\end{tabular} \\ Li et al.: Sphingolipids and Infections}

98 Zhang Y, Li X, Grassmé H, Döring G, Gulbins E: Alterations in ceramide concentration and pH determine the release of reactive oxygen species by Cftr-deficient macrophages on infection. J Immunol 2010;184:51045111.

99 Ulrich M, Worlitzsch D, Viglio S, Siegmann N, Iadarola P, Shute JK, Geiser M, Pier GB, Friedel G, Barr ML, Schuster A, Meyer KC, Ratjen F, Bjarnsholt T, Gulbins E, Döring G: Alveolar inflammation in cystic fibrosis. J Cyst Fibros 2010;9:217-227.

- 100 Bodas M, Min T, Mazur S, Vij N: Critical modifier role of membrane-cystic fibrosis transmembrane conductance regulator-dependent ceramide signaling in lung injury and emphysema. J Immunol 2011;186:602-613.

101 Keitsch S, Riethmüller J, Soddemann M, Sehl C, Wilker B, Edwards MJ, Caldwell CC, Fraunholz M, Gulbins E, Becker NKA: Pulmonary infection of cystic fibrosis mice with Staphylococcus aureus requires expression of $\alpha$-toxin. Biol Chem 2018;399:1203-1213.

102 Rada B, Lekstrom K, Damian S, Dupuy C, Leto TL: The Pseudomonas toxin pyocyanin inhibits the dual oxidase-based antimicrobial system as it imposes oxidative stress on airway epithelial cells. J Immunol 2008;181:4883-4893.

103 Matsumoto A, Comatas KE, Liu L, Stamler JS: Screening for nitric oxide-dependent protein-protein interactions. Science 2003;301:657-661.

104 Novgorodov SA, Voltin JR, Gooz MA, Li L, Lemasters JJ, Gudz TI: Acid sphingomyelinase promotes mitochondrial dysfunction due to glutamate-induced regulated necrosis. J Lipid Res 2018;59:312-329.

105 Tong SYC, Davis JS, Eichenberger E, Holland TL, Fowler VGJ: Staphylococcus aureus infections: epidemiology, pathophysiology, clinical manifestations, and management. Clin Microbiol Rev 2015;28:603-661.

106 Grundmann H, Aires-de-Sousa M, Boyce J, Tiemersma E: Emergence and resurgence of meticillin-resistant Staphylococcus aureus as a public-health threat. Lancet 2006;368:874-885.

107 Esen M, Schreiner B, Jendrossek V, Lang F, Fassbender K, Grassmé H, Gulbins E: Mechanisms of Staphylococcus aureus induced apoptosis of human endothelial cells. Apoptosis 2001;6:431-439.

108 Grassmé H, Carpinteiro A, Edwards MJ, Gulbins E, Becker KA: Regulation of the inflammasome by ceramide in cystic fibrosis lungs. Cell Physiol Biochem 2014;34:45-55.

109 Li C, Wu Y, Riehle A, Orian-Rousseau V, Zhang Y, Gulbins E, Grassmé H: Regulation of Staphylococcus aureus Infection of Macrophages by CD44, Reactive Oxygen Species, and Acid Sphingomyelinase. Antioxid Redox Signal 2017; DOI:10.1089/ars.2017.6994.

$110 \mathrm{Gu}$ Y, Dee CM, Shen J: Interaction of free radicals, matrix metalloproteinases and caveolin-1 impacts bloodbrain barrier permeability. Front Biosci (Schol Ed) 2011;3:1216-1231.

111 Rochfort KD, Collins LE, Murphy RP, Cummins PM: Downregulation of blood-brain barrier phenotype by proinflammatory cytokines involves NADPH oxidase-dependent ROS generation: consequences for interendothelial adherens and tight junctions. PLoS One 2014;9:e101815.

112 Abdul-Muneer PM, Chandra N, Haorah J: Interactions of oxidative stress and neurovascular inflammation in the pathogenesis of traumatic brain injury. Mol Neurobiol 2015;51:966-979.

113 Bauer J, Liebisch G, Hofmann C, Huy C, Schmitz G, Obermeier F, Bock J: Lipid alterations in experimental murine colitis: role of ceramide and imipramine for matrix metalloproteinase-1 expression. PLoS One 2009;4:e7197.

114 Butler A, Gordon RE, Gatt S, Schuchman EH: Sperm abnormalities in heterozygous acid sphingomyelinase knockout mice reveal a novel approach for the prevention of genetic diseases. Am J Pathol 2007;170:20772088.

115 Bauer J, Huy C, Brenmoehl J, Obermeier F, Bock J: Matrix metalloproteinase-1 expression induced by IL1 beta requires acid sphingomyelinase. FEBS Lett 2009;583:915-920.

116 Chung HY, Hupe DC, Otto GP, Sprenger M, Bunck AC, Dorer MJ, Bockmeyer CL, Deigner H-P, Gräler MH, Claus RA: Acid sphingomyelinase promotes endothelial stress response in systemic inflammation and sepsis. Mol Med 2016;22:412-423.

117 Becker KA, Fahsel B, Kemper H, Mayeres J, Li C, Wilker B, Keitsch S, Soddemann M, Sehl C, Kohnen M, Edwards MJ, Grassmé H, Caldwell CC, Seitz A, Fraunholz M, Gulbins E: Staphylococcus aureus AlphaToxin Disrupts Endothelial-Cell Tight Junctions via Acid Sphingomyelinase and Ceramide. Infect Immun 2017;86:pii:e00606-e00617.

118 Parker MW, Feil SC: Pore-forming protein toxins: from structure to function. Prog Biophys Mol Biol 2005;88:91-142. 


\section{Cellular Physiology Cell Physiol Biochem 2019;52:280-301 \begin{tabular}{ll|l} 
and Biochemistry & DOl: 10.33594/000000021 & P 2019 The Author(s). Published by \\
Published online: 28 February 2019 & Cell Physiol Biochem Press GmbH\&Co. KG
\end{tabular} \\ Li et al.: Sphingolipids and Infections}

- 119 Bhakdi S, Tranum-Jensen J: Alpha-toxin of Staphylococcus aureus. Microbiol Rev 1991;55:733-751.

- 120 Berube BJ, Bubeck Wardenburg J: Staphylococcus aureus $\alpha$-toxin: nearly a century of intrigue. Toxins 2013;5:1140-1166.

- 121 Ma J, Gulbins E, Edwards MJ, Caldwell CC, Fraunholz M, Becker KA: Staphylococcus aureus $\alpha$-Toxin Induces Inflammatory Cytokines via Lysosomal Acid Sphingomyelinase and Ceramides. Cell Physiol Biochem 2017;43:2170-2184.

122 Irvine AD, McLean WHI, Leung DYM: Filaggrin mutations associated with skin and allergic diseases. N Engl J Med 2011;365:1315-1327.

123 Moore CL, Osaki-Kiyan P, Haque NZ, Perri MB, Donabedian S, Zervos MJ: Daptomycin versus vancomycin for bloodstream infections due to methicillin-resistant Staphylococcus aureus with a high vancomycin minimum inhibitory concentration: a case-control study. Clin Infect Dis 2012;54:51-58.

124 Kanafani ZA, Kourany WM, Fowler VGJ, Levine DP, Vigliani GA, Campion M, Katz DE, Corey GR, Boucher HW: Clinical characteristics and outcomes of diabetic patients with Staphylococcus aureus bacteremia and endocarditis. Eur J Clin Microbiol Infect Dis 2009;28:1477-1482.

125 Moore CL, Lu M, Cheema F, Osaki-Kiyan P, Perri MB, Donabedian S, Haque NZ, Zervos MJ: Prediction of failure in vancomycin-treated methicillin-resistant Staphylococcus aureus bloodstream infection: a clinically useful risk stratification tool. Antimicrob Agents Chemother 2011;55:4581-4588.

- 126 Cosma CL, Sherman DR, Ramakrishnan L: The secret lives of the pathogenic mycobacteria. Annu Rev Microbiol 2003;57:641-676.

127 Houben ENG, Nguyen L, Pieters J: Interaction of pathogenic mycobacteria with the host immune system. Curr Opin Microbiol 2006;9:76-85.

128 Zumla A, Schito M, Chakaya J, Marais B, Mwaba P, Migliori GB, Hoelscher M, Maeurer M, Wallis RS: World TB Day 2016: reflections on the global TB emergency. Lancet Respir Med 2016;4:249-251.

129 Schramm M, Herz J, Haas A, Krönke M, Utermöhlen 0: Acid sphingomyelinase is required for efficient phago-lysosomal fusion. Cell Microbiol 2008;10:1839-1853.

130 Truman J-P, Al Gadban MM, Smith KJ, Hammad SM: Acid sphingomyelinase in macrophage biology. Cell Mol Life Sci 2011;68:3293-3305.

131 Anes E, Kuhnel MP, Bos E, Moniz-Pereira J, Habermann A, Griffiths G: Selected lipids activate phagosome actin assembly and maturation resulting in killing of pathogenic mycobacteria. Nat Cell Biol 2003;5:793802.

132 Utermöhlen 0, Herz J, Schramm M, Krönke M: Fusogenicity of membranes: the impact of acid sphingomyelinase on innate immune responses. Immunobiology 2008;213:307-314.

133 Roca FJ, Ramakrishnan L: TNF dually mediates resistance and susceptibility to mycobacteria via mitochondrial reactive oxygen species. Cell 2013;153:521-534.

134 Thon L, Möhlig H, Mathieu S, Lange A, Bulanova E, Winoto-Morbach S, Schutze S, Bulfone-Paus S, Adam D: Ceramide mediates caspase-independent programmed cell death. FASEB J 2005;19:1945-1956.

135 Lee J, Repasy T, Papavinasasundaram K, Sassetti C, Kornfeld H: Mycobacterium tuberculosis induces an atypical cell death mode to escape from infected macrophages. PLoS One 2011;6:e18367.

136 Ebe Y, Hasegawa G, Takatsuka H, Umezu H, Mitsuyama M, Arakawa M, Mukaida N, Naito M: The role of Kupffer cells and regulation of neutrophil migration into the liver by macrophage inflammatory protein-2 in primary listeriosis in mice. Pathol Int 1999;49:519-532.

137 Miyamoto M, Emoto M, Emoto Y, Brinkmann V, Yoshizawa I, Seiler P, Aichele P, Kita E, Kaufmann SH: Neutrophilia in LFA-1-deficient mice confers resistance to listeriosis: possible contribution of granulocytecolony-stimulating factor and IL-17. J Immunol 2003;170:5228-5234.

138 Goldfine H, Wadsworth SJ: Macrophage intracellular signaling induced by Listeria monocytogenes. Microb Infect 2002;4:1335-1343.

139 Schnupf P, Portnoy DA: Listeriolysin O: a phagosome-specific lysin. Microb Infect 2007;9:1176-1187.

140 Utermöhlen 0, Karow U, Löhler J, Krönke M: Severe impairment in early host defense against Listeria monocytogenes in mice deficient in acid sphingomyelinase. J Immunol 2003;170:2621-2628.

141 Heinrich M, Wickel M, Schneider-Brachert W, Sandberg C, Gahr J, Schwandner R, Weber T, Saftig P, Peters C, Brunner J, Krönke M, Schutze S: Cathepsin D targeted by acid sphingomyelinase-derived ceramide. EMBO J 1999;18:5252-5263.

142 Sadarangani M, Pollard AJ, Gray-Owen SD: Opa proteins and CEACAMs: pathways of immune engagement for pathogenic Neisseria. FEMS Microbiol Rev 2011;35:498-514. 


\section{Cellular Physiology Cell Physiol Biochem 2019;52:280-301 \begin{tabular}{ll|l|l|l|l}
\hline DOI: 10.33594/000000021 & (O) 2019 The Author(s). Published by
\end{tabular} and Biochemistry Published online: 28 February 2019 Cell Physiol Biochem Press GmbH\&Co. KG \\ Li et al.: Sphingolipids and Infections}

143 Dehio C, Gray-Owen SD, Meyer TF: The role of neisserial Opa proteins in interactions with host cells. Trends Microbiol 1998;6:489-495.

144 Hauck CR, Grassmé H, Bock J, Jendrossek V, Ferlinz K, Meyer TF, Gulbins E: Acid sphingomyelinase is involved in CEACAM receptor-mediated phagocytosis of Neisseria gonorrhoeae. FEBS Lett 2000;478:260266.

145 Simonis A, Hebling S, Gulbins E, Schneider-Schaulies S, Schubert-Unkmeir A: Differential activation of acid sphingomyelinase and ceramide release determines invasiveness of Neisseria meningitidis into brain endothelial cells. PLoS Pathog 2014;10:e1004160.

146 Jayamani E, Mylonakis E: Effector triggered manipulation of host immune response elicited by different pathotypes of Escherichia coli. Virulence 2014;5:733-739.

147 Falcone S, Perrotta C, De Palma C, Pisconti A, Sciorati C, Capobianco A, Rovere-Querini P, Manfredi AA, Clementi E: Activation of acid sphingomyelinase and its inhibition by the nitric oxide/cyclic guanosine 3',5'-monophosphate pathway: key events in Escherichia coli-elicited apoptosis of dendritic cells. J Immunol 2004;173:4452-4463.

148 Wink DA, Hines HB, Cheng RYS, Switzer CH, Flores-Santana W, Vitek MP, Ridnour LA, Colton CA: Nitric oxide and redox mechanisms in the immune response. J Leukoc Biol 2011;89:873-891.

149 Barsacchi R, Perrotta C, Sestili P, Cantoni O, Moncada S, Clementi E: Cyclic GMP-dependent inhibition of acid sphingomyelinase by nitric oxide: an early step in protection against apoptosis. Cell Death Differ 2002;9:1248-1255.

- 150 Predescu S, Knezevic I, Bardita C, Neamu RF, Brovcovych V, Predescu D: Platelet activating factor-induced ceramide micro-domains drive endothelial NOS activation and contribute to barrier dysfunction. PLoS One 2013;8:e75846.

151 Chen CL, Lin CF, Wan SW, Wei LS, Chen MC, Yeh TM, Liu HS, Anderson R, Lin YS: Anti-dengue virus nonstructural protein 1 antibodies cause NO-mediated endothelial cell apoptosis via ceramide-regulated glycogen synthase kinase-3 $\beta$ and NF- $\kappa$ B activation. J Immunol 2013;191:1744-1752.

152 Liss V, Hensel M: Take the tube: remodelling of the endosomal system by intracellular Salmonella enterica. Cell Microbiol 2015;17:639-647.

153 Ohl ME, Miller SI: Salmonella: A model for bacterial pathogenesis. Annu Rev Med 2001;52:259-274.

- 154 McCollister BD, Myers JT, Jones-Carson J, Voelker DR, Vázquez-Torres A: Constitutive acid sphingomyelinase enhances early and late macrophage killing of Salmonella enterica serovar Typhimurium. Infect Immun 2007;75:5346-5352.

155 Bhate K, Williams HC: Epidemiology of acne vulgaris. Br J Dermatol 2013;168:474-485.

- 156 Bojar RA, Holland KT: Acne and Propionibacterium acnes. Clin Dermatol 2004;22:375-379.

- 157 Holmberg A, Lood R, Mörgelin M, Söderquist B, Holst E, Collin M, Christensson B, Rasmussen M: Biofilm formation by Propionibacterium acnes is a characteristic of invasive isolates. Clin Microbiol Infect 2009;15:787-795.

158 Nakatsuji T, Tang D-cC, Zhang L, Gallo RL, Huang C-M: Propionibacterium acnes CAMP factor and host acid sphingomyelinase contribute to bacterial virulence: potential targets for inflammatory acne treatment. PLoS One 2011;6:e14797.

159 Opal SM: Endotoxins and other sepsis triggers. Contrib Nephrol 2010;167:14-24.

160 Alexander C, Rietschel ET: Bacterial lipopolysaccharides and innate immunity. J Endotoxin Res 2001;7:167202.

161 Fenton MJ, Golenbock DT: LPS-binding proteins and receptors. J Leukoc Biol 1998;64:25-32.

162 Józefowski S, Czerkies M, Lukasik A, Bielawska A, Bielawski J, Kwiatkowska K, Sobota A: Ceramide and ceramide 1-phosphate are negative regulators of TNF-alpha production induced by lipopolysaccharide. J Immunol 2010;185:6960-6973.

163 Cuschieri J, Bulger E, Billgrin J, Garcia I, Maier RV: Acid sphingomyelinase is required for lipid Raft TLR4 complex formation. Surg Infect (Larchmt) 2007;8:91-106.

164 von Bismarck P, Winoto-Morbach S, Herzberg M, Uhlig U, Schutze S, Lucius R, Krause MF: IKK NBD peptide inhibits LPS induced pulmonary inflammation and alters sphingolipid metabolism in a murine model. Pulm Pharmacol Ther 2012;25:228-235.

165 Haimovitz-Friedman A, Cordon-Cardo C, Bayoumy S, Garzotto M, McLoughlin M, Gallily R, Edwards CKr, Schuchman EH, Fuks Z, Kolesnick R: Lipopolysaccharide induces disseminated endothelial apoptosis requiring ceramide generation. J Exp Med 1997;186:1831-1841. 


\section{Cellular Physiology Cell Physiol Biochem 2019;52:280-301

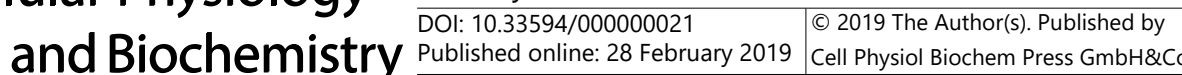 \\ Li et al.: Sphingolipids and Infections}

166 Wong ML, Xie B, Beatini N, Phu P, Marathe S, Johns A, Gold PW, Hirsch E, Williams KJ, Licinio J, Tabas I: Acute systemic inflammation up-regulates secretory sphingomyelinase in vivo: a possible link between inflammatory cytokines and atherogenesis. Proc Natl Acad Sci U S A 2000;97:8681-8686.

167 Kornhuber J, Tripal P, Reichel M, Terfloth L, Bleich S, Wiltfang J, Gulbins E: Identification of new functional inhibitors of acid sphingomyelinase using a structure-property-activity relation model. J Med Chem 2008;51:219-237.

168 Becker KA, Riethmüller J, Lüth A, Döring G, Kleuser B, Gulbins E: Acid sphingomyelinase inhibitors normalize pulmonary ceramide and inflammation in cystic fibrosis. Am J Respir Cell Mol Biol 2010;42:716724.

169 Becker KA, Tümmler B, Gulbins E, Grassmé H: Accumulation of ceramide in the trachea and intestine of cystic fibrosis mice causes inflammation and cell death. Biochem Biophys Res Commun 2010;403:368-374.

170 Ziobro R, Henry B, Edwards MJ, Lentsch AB, Gulbins E: Ceramide mediates lung fibrosis in cystic fibrosis. Biochem Biophys Res Commun 2013;434:705-709.

171 Riethmüller J, Anthonysamy J, Serra E, Schwab M, Döring G, Gulbins E: Therapeutic efficacy and safety of amitriptyline in patients with cystic fibrosis. Cell Physiol Biochem 2009;24:65-72.

172 Nährlich L, Mainz JG, Adams C, Engel C, Herrmann G, Icheva V, Lauer J, Deppisch C, Wirth A, Unger K, Graepler-Mainka U, Hector A, Heyder S, Stern M, Döring G, Gulbins E, Riethmüller J: Therapy of CF-patients with amitriptyline and placebo--a randomised, double-blind, placebo-controlled phase IIb multicenter, cohort-study. Cell Physiol Biochem 2013;31:505-512.

173 Becker KA, Henry B, Ziobro R, Tümmler B, Gulbins E, Grassmé H: Role of CD95 in pulmonary inflammation and infection in cystic fibrosis. J Mol Med (Berl) 2012;90:1011-1023.

174 Hedlund M, Duan RD, Nilsson A, Svanborg C: Sphingomyelin, glycosphingolipids and ceramide signalling in cells exposed to P-fimbriated Escherichia coli. Mol Microbiol 1998;29:1297-1306. 